See discussions, stats, and author profiles for this publication at: https://www.researchgate.net/publication/290995972

\title{
Illite occurrences related to volcanic-hosted hydrothermal mineralization in the Biga Peninsula, NW Turkey: Implications for the age and origin of fluids
}

Article in Ore Geology Reviews · January 2016

DOI: 10.1016/j.oregeorev.2016.01.001

\section{CITATIONS}

10

4 authors, including:

Omer Bozkaya

Pamukkale University

93 PUBLICATIONS 490 CITATIONS

SEE PROFILE

I. Tonguc Uysal

The Commonwealth Scientific and Industrial Research Organisation

137 PUBLICATIONS 1,495 CITATIONS

SEE PROFILE

Some of the authors of this publication are also working on these related projects:
READS

424

Q. Gulcan Bozkaya

Pamukkale University

75 PUBLICATIONS 308 CITATIONS

SEE PROFILE

Project Authigenic carbonates as natural analogues of mineralisation trapping in $\mathrm{CO} 2$ sequestration View project

Project AMIRA Project P552: Fluid flow modeling in the Mount Isa and McArthur basins View project 


\title{
Illite occurrences related to volcanic-hosted hydrothermal mineralization in the Biga Peninsula, NW Turkey: Implications for the age and origin of fluids
}

\author{
Ömer Bozkaya a , Gülcan Bozkaya a ${ }^{\text {a I. Tonguç Uysal }}{ }^{\text {b,c }}$, David A. Banks ${ }^{\text {d }}$ \\ a Pamukkale University, Department of Geological Engineering, 20070 Denizli,Turkey \\ ${ }^{\mathrm{b}}$ Hacettepe University, Department of Geological Engineering, 06800 Ankara, Turkey \\ c Queensland Geothermal Energy Centre of Excellence, The University of Queensland, Queensland 4072, Australia \\ d School of Earth and Environment, University of Leeds, Woodhouse Lane, Leeds LS2 9JT, United Kingdom
}

\section{A R T I C L E I N F O}

\section{Article history:}

Received 1 October 2015

Received in revised form 2 January 2016

Accepted 5 January 2016

Available online 9 January 2016

\section{Keywords:}

Base metal deposit

Hydrothermal alteration

Clay mineralogy and geochemistry

Biga Peninsula

Turkey

\begin{abstract}
A B S T R A C T
A different approach to investigate the origin of fluids, temperature conditions, age of hydrothermal activity of mineralization in the Biga Peninsula, (Koru, Tesbihdere and Kumarlar) employed mineralogical (illite Kübler Index, $b$ cell dimension, polytype) and geochemical (major, trace/REE, $\mathrm{O}-\mathrm{H}$ stable isotope and $\mathrm{Rb} / \mathrm{Sr}$ dating) methods. The Kübler Index (KI) values of illites indicate different temperature conditions, such as low temperature (high-grade diagenesis) for Koru deposit, and high temperature (anchizone) for the Tesbihdere and Kumarlar deposits. The textural, mineralogical and geochemical data from illites show that these have potential for estimating the age of hydrothermal activity and fluid characteristics. Both mineralogical (high grade diagenetic to anchizonal KI, $1 M$ polytype, low $d_{060}$ values) and geochemical (similar major and trace element composition to host-rocks, low octahedral $\mathrm{Mg}+\mathrm{Fe}$ contents, oxygen and hydrogen isotope composition) data are compatible with commonly known hydrothermal illites. Stable isotope data of illites are well matched to similar data from fluid inclusions, which indicate mainly magmatic fluids. The $\mathrm{Rb} / \mathrm{Sr}$ age (22.4 $\pm 2.3 \mathrm{Ma}$ : latest Oligocene and lowest Miocene) of the illites coincides with plutonic intrusions that are the main instigators of hydrothermal activities related to the extensional tectonic regime in the Biga Peninsula. The mineralogical and geochemical data of illites have some important advantages with respect to the use of fluid inclusions in determining $\delta \mathrm{D}$ of hydrothermal fluids thereby leading to better understanding ore-forming hydrothermal conditions.
\end{abstract}

(c) 2016 Elsevier B.V. All rights reserved.

\section{Introduction}

For many years constraining fluid compositions and temperatures of hydrothermal ore deposits has relied on fluid inclusion studies of quartz, or other gangue minerals, associated with the deposition of the ore minerals in only a few of which can inclusions be directly observed, i.e. sphalerite (see Roedder, 1984 for a compilation of the use of fluid inclusions). The origin and evolution of ore-forming fluids is commonly inferred from a combination of oxygen isotopes in quartz and the hydrogen isotopic composition of fluids trapped within gangue or ore minerals (Campbell and Larson, 1988). As these are bulk techniques the data's validity, requires there to be only a single generation of inclusions or quartz both of which represent the ore forming process. However, this is frequently not the case and analyses are used where there are different generations of fluid that may be of a different origin. The results are therefore an average of the different populations sampled. In cases such as epithermal or porphyry mineralization, fluids with different $\mathrm{P}-\mathrm{T}-\mathrm{X}$ characteristics can be identified by microthermometry with the different fluids being a mixture of magmatic and the local meteoric water. The analyses plot on $\delta \mathrm{D}$ vs $\delta^{18} \mathrm{O}$ diagrams somewhere between the magmatic water box and the meteoric water line, depending either on the degree of mixing of the fluids or the proportion of magmatic and later meteoric inclusions that are contained in the samples. However, these can still be valid in assigning the source of the fluids. In many cases, however, the fluid system is not so simple and the analyses from mixed fluid populations cannot be easily deciphered. An alternative, or addition, to the use of fluid inclusions is to determine the $\delta \mathrm{D}$ and $\delta^{18} \mathrm{O}$ of clay/phyllosilicate minerals, which form as hydrothermal alteration products (e.g., Bechtel and Hoernes, 1990; Uysal et al., 2001; Golding et al., 2006; Middleton et al., 2014, 2015). These can be more reliable and directly links the fluid to an effect, i.e., alteration and production of new mineral phases.

In hydrothermal systems, the factors controlling clay formation (kaolinization, illitization and/or sericitization) processes (temperature, time, fluid composition, fluid/rock ratio) may differ from those of burial diagenesis. Time has a negligible effect because the formation generally occurs during a short period (or short-lived geothermal systems; Jennings and Thompson, 1986; Ramseyer and Boles, 1986) and probably during a single event (Bauluz et al., 2002; Bauluz, 2007). The effect of fluid composition and the fluid/rock ratio on clay formation in 

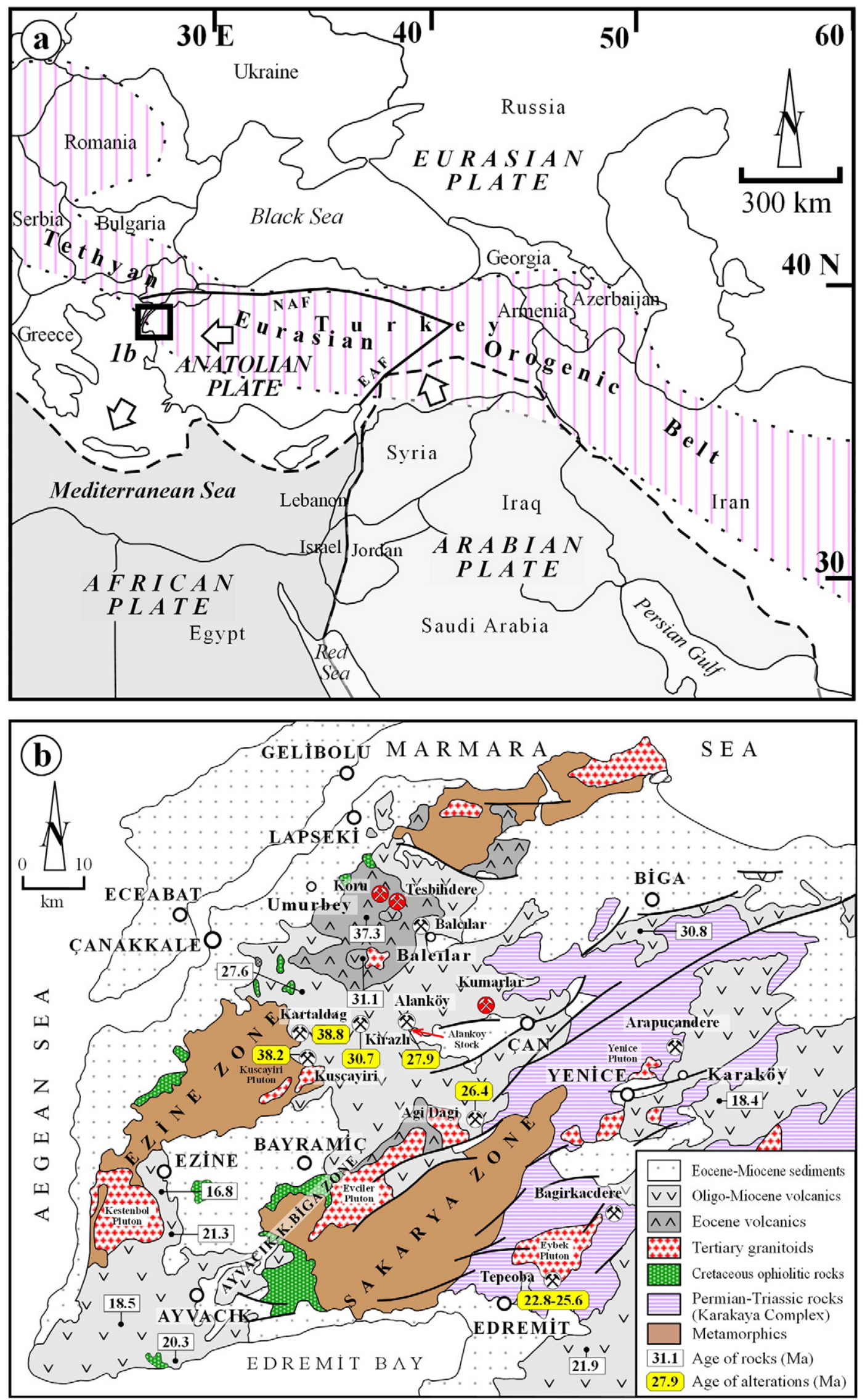

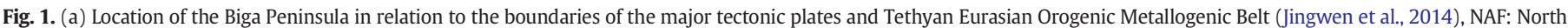

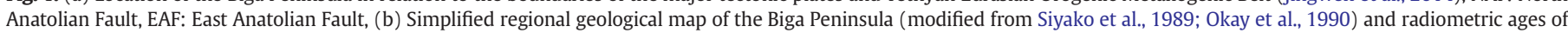
volcanic and plutonic rocks and alteration related mineralizations (Ercan et al., 1995; Aldanmaz et al., 2000; Yigit, 2012). 
hydrothermal environments is more significant (e.g., Whitney, 1990; Buatier et al., 1992; Harvey and Browne, 1991; Inoue and Kitagawa, 1994; Inoue, 1995), and the crystallinity of clay minerals is largely controlled by fluid temperature (Browne and Ellis, 1970; Duba and William-Jones, 1983; Hedenquist and Browne, 1989; Ji and Browne, 2000; Zhangdong et al., 2001, 2002; Fukuchi et al., 2014). If clay minerals precipitated in equilibrium with the fluid (without any kinetic isotope fractionation) the $\mathrm{H}$ - and $\mathrm{O}$ - isotope composition of the clays can be used to infer the fluid isotope composition (if the fluid temperature is known) or temperature (if the fluid isotopic composition is known). Radiometric dating of illitic clay minerals also provides information on the timing of the hydrothermal activity (e.g., Zwingmann et al., 1999; Uysal et al., 2001; Uysal et al., 2011; Middleton et al., 2014). The advantage of using illite is its higher stability in relatively high temperature environments (Velde and Vasseur, 1992; Pollastro, 1993), compared to the other, more easily, weathered clay minerals, such as chlorite, kaolinite and mixed-layer illite-smectite. Illite that formed in hydrothermal alteration environments and was not affected by later fluid flow and thermal events remain stable, even at the conditions of porphyry copper mineralization (Zhangdong et al., 2001, 2002), therefore it can be used to understand the formation conditions, fluid source and water/rock ratio (e.g., Whitney, 1990; Inoue and Kitagawa, 1994).

In this study, our objective was to investigate hydrothermal illites in terms of the thermal conditions and origin of hydrothermal fluids as well as age of alteration, and to correlate this with fluid inclusion data. Thus, we test the possible advantages of mineralogical (clay assemblages, Kübler Index-KI, polytype and $b$ cell dimension of illites) and geochemical (major, trace elements, stable and radiogenic isotopes) data from illites that may elucidate the physico-chemical characteristics of hydrothermal systems from a different perspective.

\section{Geological framework}

The deposits studied (Koru, Tesbihdere-Sahinli and Kumarlar) are aligned NW-SE, and located in the Lapseki and Çan districts of the Biga Peninsula, NW Turkey (Fig. 1a, b). Their general characteristics are comparable with low to intermediate sulphidation volcanic-hosted epithermal base-metal-Au deposits. The Biga Peninsula is part of the Tethyan Eurasian Metallogenic Belt (Fig. 1a, Jankovic, 1986; Yigit, 2012) and has a complicated geologic and tectonic history due to the collision of the different continental fragments and their amalgamation resulting from the convergence between the Anatolide-Tauride platform (Gondwana) and the Pontides (Laurasia). The Pre-Cenozoic rocks of the Biga Peninsula are sub-divided into three zones from the northwest to southeast: (1) the Ezine zone, Permian metasedimentary and Permo-Triassic ophiolitic rocks, (2) the AyvacıkKarabiga zone, eclogite-bearing ophiolitic mélange and Late Triassic limestone blocks and (3) the Sakarya zone, Permian metamorphic rocks of the Kazdağ Group and Permo-Triassic sedimentary and

W

\section{E}

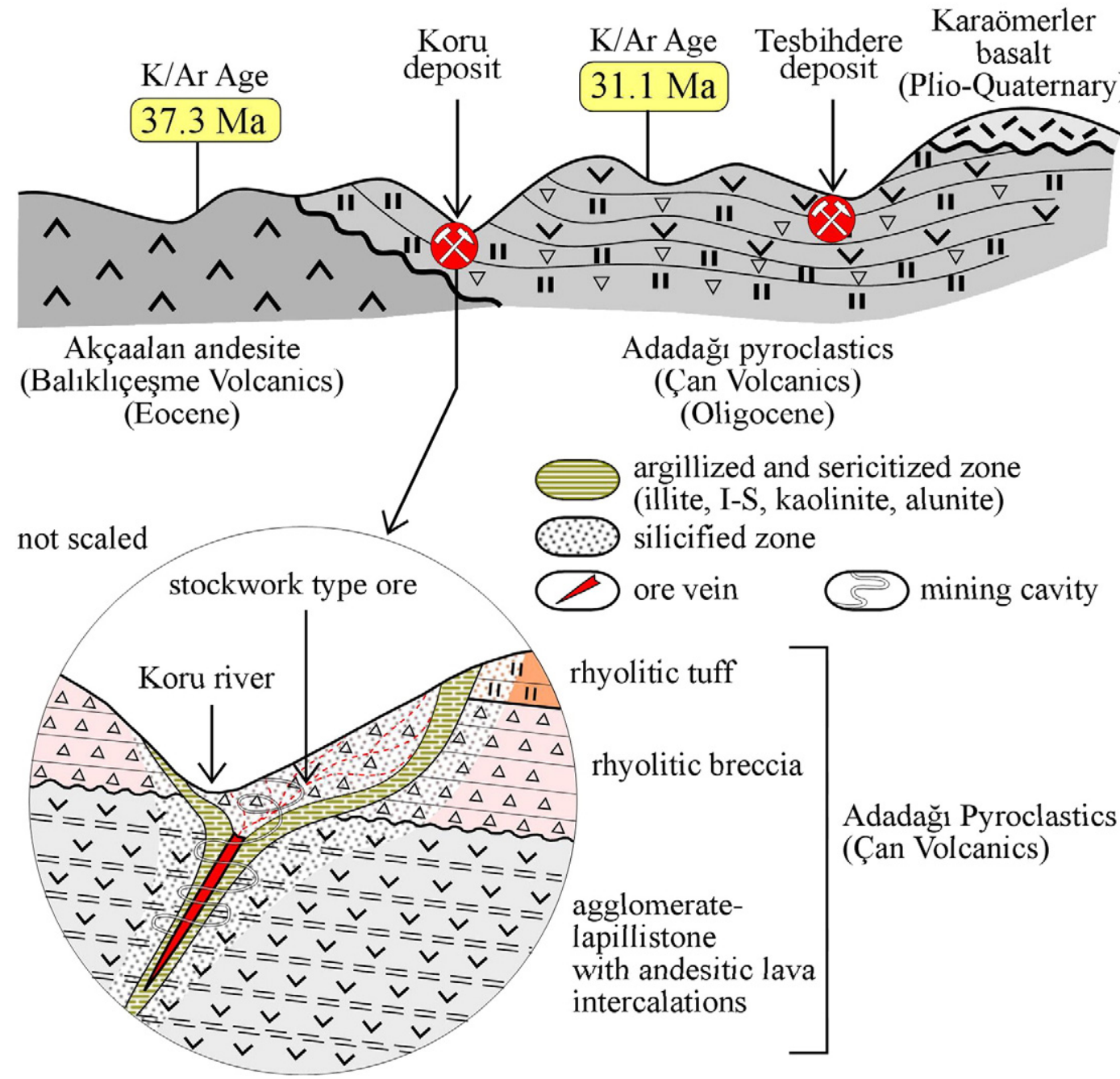

Fig. 2. The setting Koru and Tesbihdere deposit on the geologic cross-section (upper) and vertical distribution of lithology, ore and alteration zones in the Koru deposit (lower). 
magmatic rocks of the Karakaya Complex (Fig. 1b; Okay et al., 1990, 1991). The ophiolitic rocks are represented by a Cretaceous ophiolitic melange, consisting of partly serpentinized harzburgites (Okay et al., 1990). Tertiary to Miocene volcanism covers extensive areas and hosts numerous important metallic and industrial deposits in the Biga Peninsula (e.g., Yigit, 2009, Fig. 1b). The Tertiary volcanism started in the Eocene with andesitic lava, tuff and agglomerate with a medium-K calc-alkaline character (Baliklicesme volcanics or Akcaalan volcanics) and continued through the Oligocene with andesite, trachyandesite, dacite, rhyodacite, rhyolite lava, tuff and agglomerate with a high-K calc-alkaline character (Çan volcanics or Adadagi pyroclastics). Early Miocene volcanism is characterized by andesite, dacite, rhyodacite (Behram volcanics or Dededagi dacite), followed by alkaline olivine basaltic lava (Ezine basalt) in the Late Miocene (Yilmaz, 1990; Ercan et al., 1995, 1998; Yilmaz et al., 2001). The three units were defined by Ercan et al. (1995), Siyako et al. (1989) and Bozkaya (2001):
Baliklicesme volcanics, Çan volcanics, Behram volcanics and Ezine basalt were taken from Ercan et al. (1995), Akcaalan volcanics from Siyako et al. (1989), Adadagi pyroclastics, Dededagi dacite and Karaomerler basalt from Bozkaya (2001). Plutonic rocks (granite, syenite, granodiorite, quartz monzonite, quartz monzodiorite) appeared in the Late Cretaceous and continued through the Eocene, Oligocene and into the early Miocene (Birkle and Satir, 1995; Yilmaz et al., 2001). The radiometric ages of volcanic rocks in the region are mainly from $\mathrm{K} / \mathrm{Ar}$ (Ercan et al., 1995; Aldanmaz et al., 2000) and some Ar/Ar dating (Ece et al., 2008) from different areas dispersed between Gökçeada to Edremit (Fig. 1b). The Oligocene and Miocene volcanics cannot be distinguished in the map (Fig. 1b), as detailed maps (1:25.000) do not exist at present for volcanic rocks in the Peninsula.

The three deposits are similar to each other in terms of their style of mineralization with veins at depth and disseminations and stockworks in the upper parts. The host-rocks are Oligocene pyroclastics
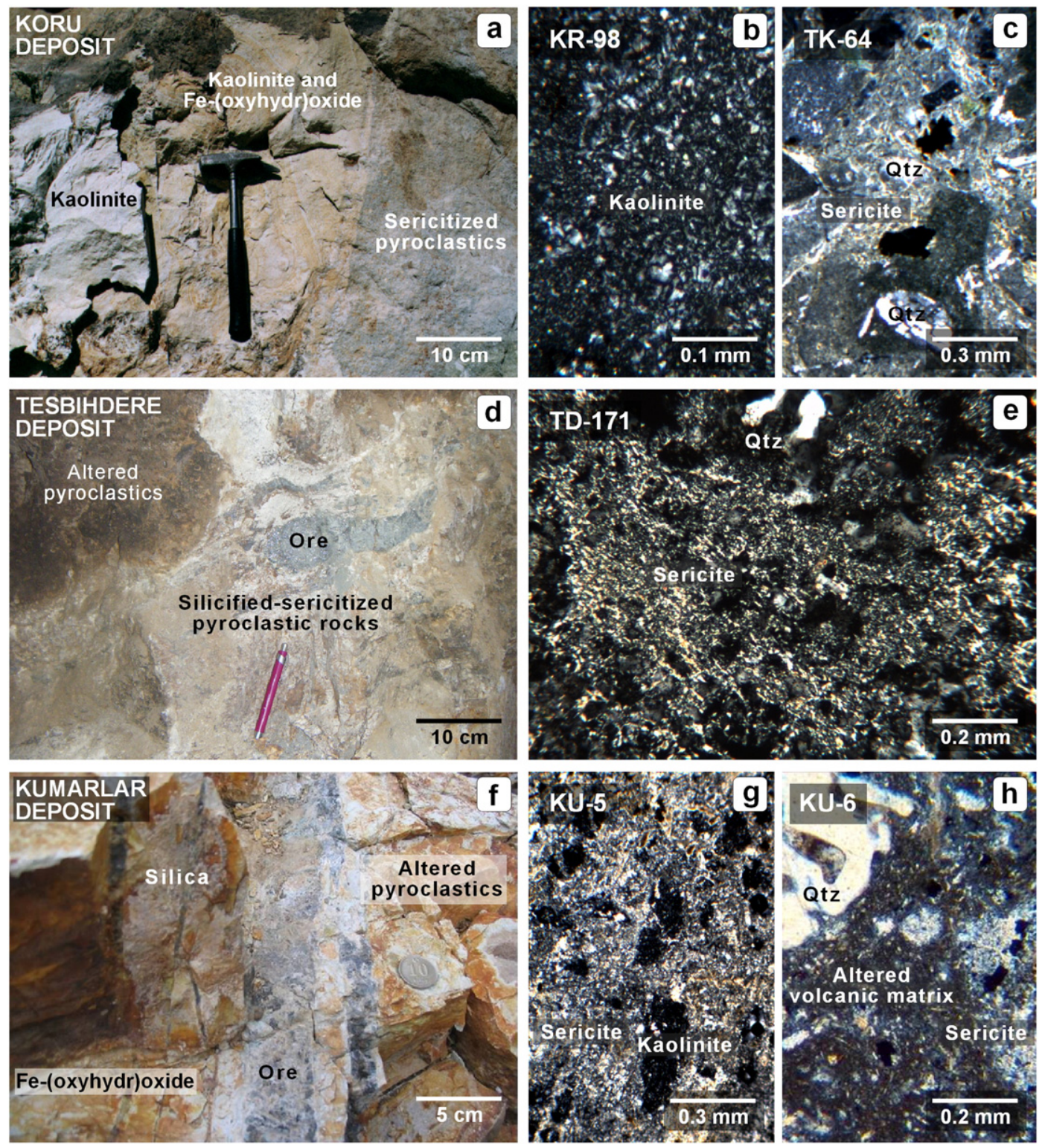

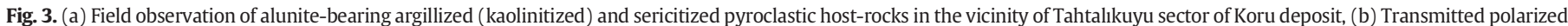

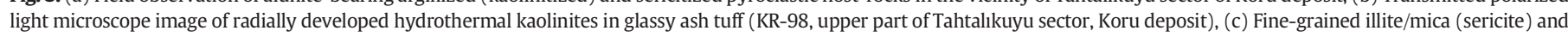

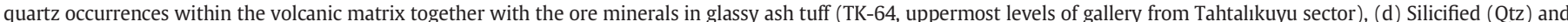

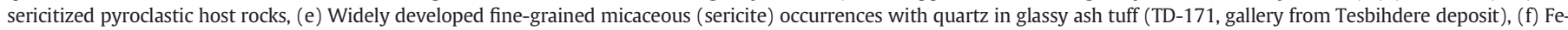

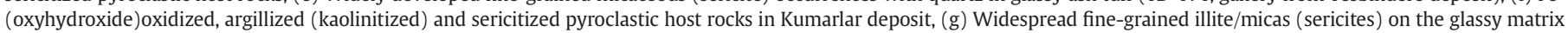
and kaolinites within the pores, (h) Fine grained scaly illite/mica (sericite) occurrences within the glassy matrix and primary (or magmatic) corroded quartz. 
and the ore (galena, sphalerite) and gangue minerals (quartz, barite) are common to all deposits. The pyroclastic rocks, agglomerates, breccias, lapillistones and tuffs, are found in the Tahtalıkuyu sector of the Koru area (Fig. 2). Greenish colored agglomerates and lapillistones with andesite interlayers are located in the lower part, yellowish gray colored highly silicified rhyolitic breccias in the middle with silicified rhyolitic tuffs toward the top (Bozkaya and Gokce, 2001, 2009). According to the distribution of the pyroclastic rocks, the Tesbihdere and Kumarlar areas are more representative of deeper parts, whereas those of the Koru area are more representative of the upper parts of the volcanic-volcanogenic succession. Such upper level rhyolitic breccias and tuffs were described as volcanic cones by Yanagiya and Sato (1989) and Bozkaya (2001). The ore veins are typically surrounded by a silicified, argillic-sericitic alteration zone up to tens of meters in width.

\section{Analytical methods}

A total of 25 hydrothermally altered volcanic and volcaniclastic rock samples were selected from hundreds of samples collected from the argillic zones of the three volcanic-hosted vein type of $\mathrm{Pb}-\mathrm{Zn}$ deposits (Koru, Tesbihdere and Kumarlar) and analyzed by optical and electron microscopy, X-ray diffraction (XRD) and geochemistry, major, trace, stable and radiometric isotopes: $\mathrm{O}, \mathrm{H}, \mathrm{Rb} / \mathrm{Sr}$. The ore mineralogy and fluid inclusion characteristics of these deposits were previously studied by Bozkaya and Gokce (2001, 2009), Bozkaya and Celik (2010) and Bozkaya et al. (2014).

Electron microscope investigations were undertaken on gold-coated samples using a Carl Zeiss Supra 40 VP Field Emission Scanning Electron Microscope (FE-SEM) at Pamukkale University (Denizli, Turkey).
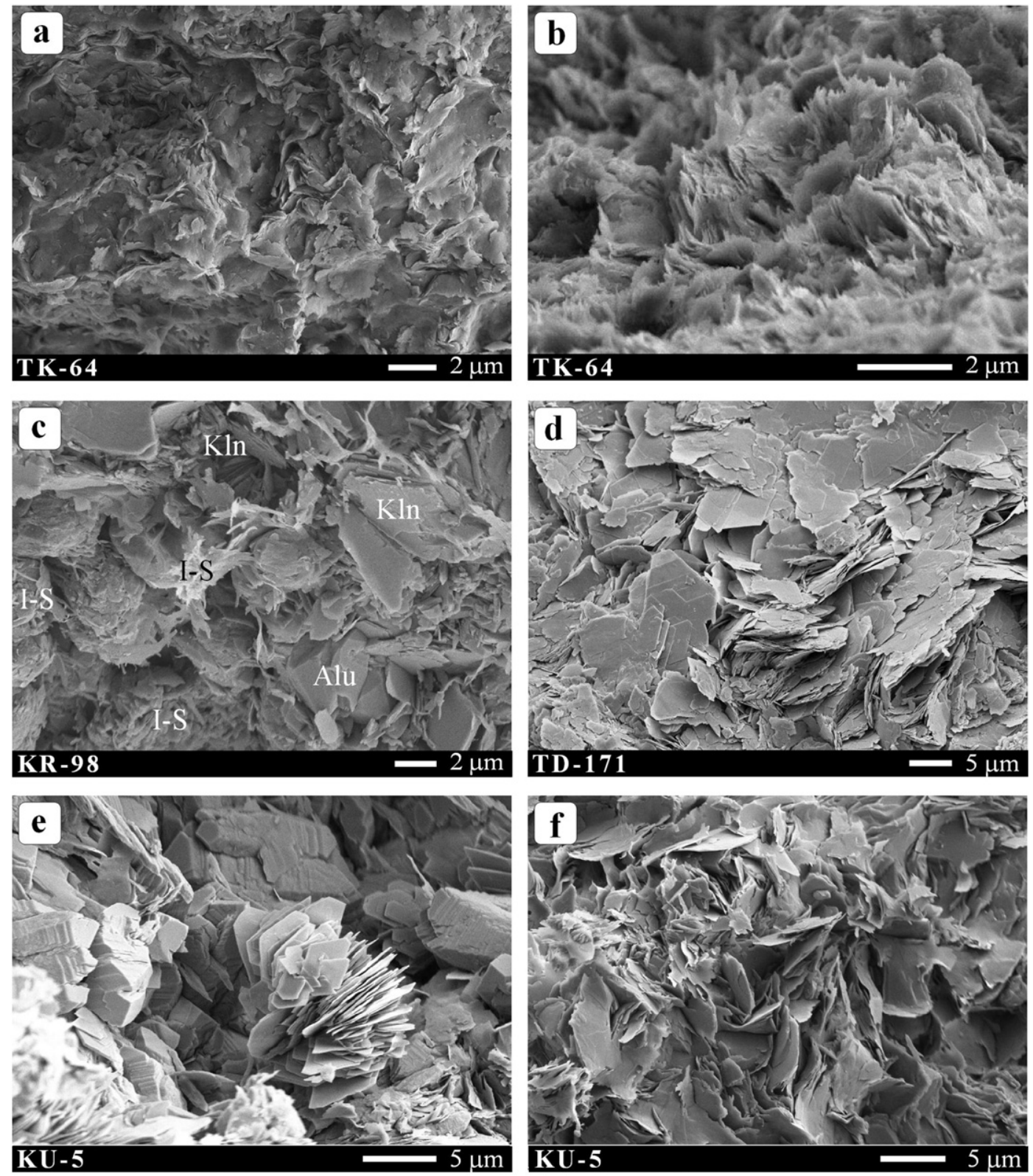

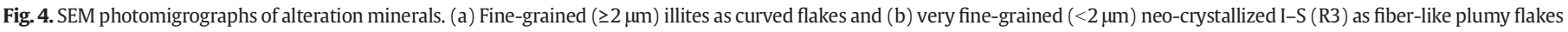

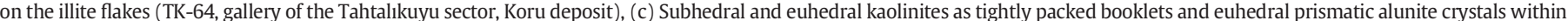

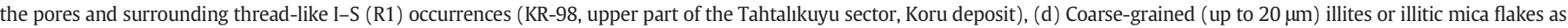

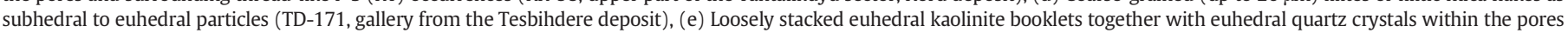
and (f) Coarse grained (up to $10 \mu \mathrm{m}$ ) subhedral illite plates or flakes (KU-5, Kumarlar deposit). 
Table 1

Bulk and clay-sized mineral composition of hydrothermally altered volcanic and pyroclastic rocks.

\begin{tabular}{|c|c|c|c|c|c|c|c|c|c|c|c|c|}
\hline \multirow[t]{2}{*}{ Sample } & \multirow[t]{2}{*}{ Lithology } & \multicolumn{5}{|c|}{ Whole rock } & \multicolumn{6}{|c|}{ Clay fraction } \\
\hline & & Quartz & Feldspar & Clay & Zeolite & Alunite & Illite & Chlorite & Kaolinite & $\mathrm{I}-\mathrm{S}$ & $\mathrm{C}-\mathrm{S}$ & Smectite \\
\hline \multicolumn{13}{|c|}{ Koru deposit } \\
\hline EK-25 & Lithic tuff & + & ++ & ++ & & & ++ & +++ & & & & \\
\hline TK-27 & Lithic tuff & +++ & + & + & & & + & & ++ & ++ & & \\
\hline TK-64 & Glassy tuff & + & + & +++ & & & + & & & ++++ & & \\
\hline TK-98 & Glassy tuff & ++ & & +++ & & \pm & & & +++++ & \pm & & \\
\hline TK-99 & Lithic tuff & +++ & & ++ & & & & & +++++ & & & \\
\hline TK-100 & Glassy tuff & ++ & ++ & + & & & & & +++++ & & & \\
\hline TK-101 & Glassy tuff & ++ & ++ & + & & & + & & ++++ & & & \\
\hline TK-102 & Lithic tuff & ++ & + & + & + & & ++ & & ++ & + & & \\
\hline TK-122 & Glassy tuff & +++ & + & + & & & +++ & & ++ & & & \\
\hline TK-129 & Glassy tuff & +++ & + & + & & & +++++ & & & & & \\
\hline TK-143 & Glassy tuff & + & +++ & + & & & + & & + & + & & ++ \\
\hline KR-186 & Glassy tuff & + & +++ & + & & & +++ & ++ & & & & \\
\hline KR-222 & Glassy tuff & +++ & ++ & & & & & & +++++ & & & \\
\hline KR-244 & Lithic tuff & + & +++ & + & & & & +++++ & & & & \\
\hline KR-264 & Glassy tuff & +++ & + & + & & & & & & & & \\
\hline KR-275 & Glassy tuff & + & + & +++ & & & ++ & \pm & & & & +++ \\
\hline \multicolumn{13}{|c|}{ Tesbihdere deposit } \\
\hline TD-171 & Altered tuff & +++ & & ++ & & & +++++ & & & & & \\
\hline \multicolumn{13}{|c|}{ Kumarlar deposit } \\
\hline KU-4 & Glassy tuff & ++ & + & ++ & & & ++++ & & + & & & \\
\hline KU-5 & Glassy tuff & +++ & & ++ & & & +++ & & ++ & & & \pm \\
\hline KU-6 & Glassy tuff & +++ & & ++ & & & +++++ & & \pm & & & \\
\hline KU-15 & Glassy tuff & ++ & + & ++ & & & +++ & & + & & & + \\
\hline KU-20 & Glassy tuff & +++ & & ++ & & & +++++ & & & & & \\
\hline KU-21 & Glassy tuff & +++ & & ++ & & & +++++ & & & & & \\
\hline KU-35 & Glassy tuff & ++ & ++ & + & & & +++ & & + & & & + \\
\hline KU-41 & Andesite & + & +++ & + & & & ++ & ++ & & & + & \\
\hline
\end{tabular}

I-S: mixed-layered illite-smectite, C-S = mixed-layered chlorite-smectite, $+: 20 \%, \pm$ : rare.

XRD analyses were undertaken with a Rigaku diffractometer (DMAX IIIC) in the Cumhuriyet University (Sivas, Turkey) with the following settings: Cu-K $\alpha, 35 \mathrm{kV}, 15 \mathrm{~mA}$, slits (divergence $=1^{\circ}$, scatter $=1^{\circ}$, receiving $=0.15 \mathrm{~mm}$, receiving-monochromator $=0.30 \mathrm{~mm})$, scan speed $1^{\circ} 2 \theta / \mathrm{min}$. Clay fractions $(<2 \mu \mathrm{m})$ were separated by the sedimentation method and analyzed under normal (air-dried at $25^{\circ} \mathrm{C}$ ), ethylene glycolated EG (in a desiccator at $60{ }^{\circ} \mathrm{C}$ for $16 \mathrm{~h}$ ) and heat $\left(490{ }^{\circ} \mathrm{C}\right.$ for $4 \mathrm{~h}$ ) conditions. Fine grained fractions ( $2-1 \mu \mathrm{m}, 1-0.5 \mu \mathrm{m},<0.5 \mu \mathrm{m})$ were separated by centrifuge.

The half-height width of $10 \AA$ illite peaks (Kübler Index-KI, Kübler, 1968) were calibrated by Crystallinity Index Standards (CIS, Warr and Rice, 1994). All KI values are given as recalculated CIS values. Illite/Kwhite mica $d_{060,331}$ were measured by calibrating against the (211) peak of quartz $\left(2 \theta=59.982^{\circ}, \mathrm{d}=1.541 \AA\right)$ as an internal standard. Only pure and nearly pure illites were used for $d_{060,331}$ determinations. The equation of Guidotti et al., 1992 was used for the estimation of octahedral Fe + Mg against $d_{060,331}$ values of illite.

The contents of swelling smectite layers (smectite) in illites and ordering type (Reichweite $=R$, Jagodzinski, 1949; Reynolds, 1980) of I-S were determined following the XRD methods of Moore and Reynolds (1997). NEWMOD (Reynolds, 1985) and WINFIT (Krumm, 1996) programs were also applied for precise interpretation of mixedlayer clay minerals. Mean crystallite sizes and contents of swelling (smectitic) layers in illites were estimated using the NEWMOD-based graphs (KI vs Ir; Intensitiy Ratio of Środoń, 1984) calculated by Eberl and Velde (1989).

Illite polytypes for randomly oriented pure illite samples have been distinguished with the diagnostic peaks suggested by Bailey (1988). To determine the $2 M_{1}$ and $1 M$ and $1 M_{d} \%$ contents of ilite/ muscovites, the ratios of $(2.80 \AA) /(2.58 \AA)$ and $(3.07 \AA) /(2.58 \AA)$ peak areas for $2 M_{1}$ and $1 M$ respectively were used, as proposed by Grathoff and Moore (1996). WINFIT decomposition by profile fitting was used for determination of areas of the specific peaks of polytypes.
For major oxide element analysis, two bulk volcanic rocks and five pure illite samples were analyzed using Rigaku 3270 and Spectro Xepos III model X-ray fluorescence (XRF) spectrometers, at the Cumhuriyet University (Sivas) and Pamukkale University (Denizli, Turkey) respectively. The estimated precision and accuracy of the geochemical analyses are $\pm 2 \%$ for major oxides. Loss on ignition (LOI) of samples, after drying for $16 \mathrm{~h}$ at $110^{\circ} \mathrm{C}$, corresponds to the total of water and volatiles as a wt.\% after heating at $1000^{\circ} \mathrm{C}$.

For trace element analysis, clay samples were dissolved with a mixture of HF and nitric acids on a hotplate, then evaporated to dryness, refluxed twice with nitric acid and dissolved in $2 \mathrm{~N}$ nitric acid. Aliquots of the solutions were spiked with internal standards, diluted and analyzed on a Thermo X-series 1 quadrupole inductively coupled plasma mass spectrometer (ICP-MS) in the Radiogenic Isotope Laboratory at the University of Queensland (RIF, UQ). Sample preparation and analytical procedures used were similar to those of Eggins et al. (1997), except that Tm was not used as an internal standard and duplicate low-pressure digestions of W-2, US Geological Survey diabase standard, were used as the calibration standard. BIR-1, AGV1, AGV2 and G2 were run as unknown. The ${ }^{156} \mathrm{CeO} /{ }^{140} \mathrm{Ce}$ ratio for the run was 0.016. Long-term precision (RSD) was based on duplicate analyses of the duplicate digestions of AGV1, while precision for the run was based on five duplicate analyses of $\mathrm{W}-2$ which were better than $3 \%$ for most elements, except for $\mathrm{Li}, \mathrm{Zn}, \mathrm{Mo}, \mathrm{Cd}$, and Cs, which ranged between 5\% ( $\mathrm{Li}, \mathrm{Cd}$ and $\mathrm{Cs}$ ) and 15\% (Zn).

For stable isotope analysis, oxygen was extracted from sample powders using a $\mathrm{CO}_{2}$-laser and $\mathrm{BrF}_{5}$ (Sharp, 1990). Samples and standards were heated overnight to $150{ }^{\circ} \mathrm{C}$ prior to loading into the vacuum extraction line. These were evacuated for approximately $6 \mathrm{~h}$. Blank $\mathrm{BrF}_{5}$ runs were repeated until the yield was less than $0.2 \mu$ moles oxygen. Oxygen yields were recorded and the $\mathrm{CO}_{2}$ gas analyzed with a GEO20-20 Mass Spectrometer. Oxygen isotope values are reported in the standard $\delta^{18} \mathrm{O}$ notation, relative to $\mathrm{V}$-SMOW after normalization to the international quartz standard NBS-28 using a value 

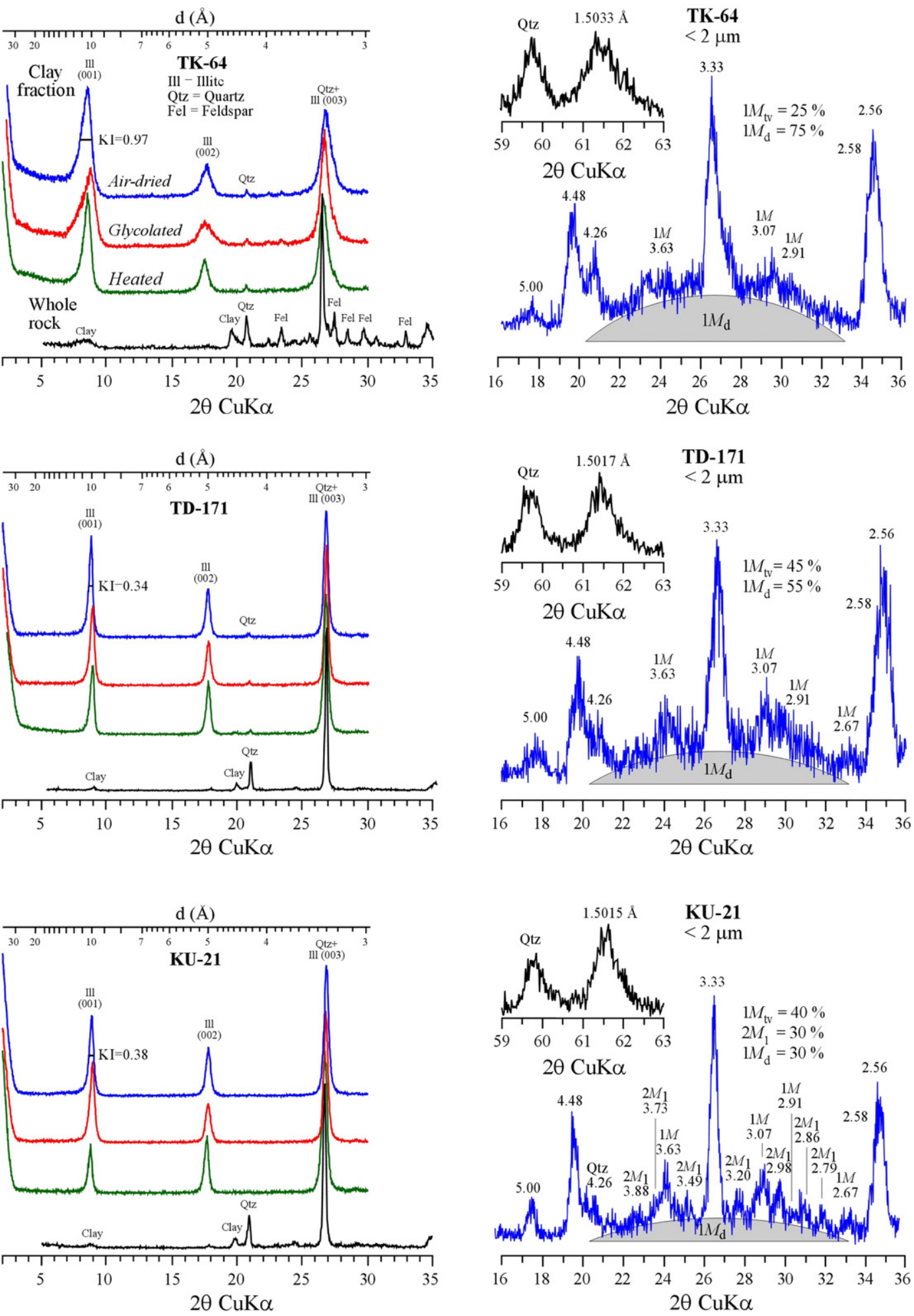

Fig. 5. XRD patterns of bulk and clay fraction compositions, $b$ cell dimensions and polytypes of pure and nearly pure illite samples.

of +9.6 per mil (\%o). Values for four NBS-28 standards, analyzed with the samples, had values that varied by less than $0.15 \%$. Hydrogen isotope analyses were conducted on a HEKAtech high temperature elemental analyzer coupled with a GV Instruments IsoPrime mass spectrometer. Samples were pyrolyzed at $1450{ }^{\circ} \mathrm{C}$, in silver capsules. All samples were analyzed in triplicate and the results are reported with respect to V-SMOW, normalized to the international standards IAEA-CH-7, NBS30 and NBS22 with reported $\delta$ D values of $-100 \%$,
$-66 \%$ and $-118 \%$. The external precision for these measurements is better than $2 \%$.

For the Rb-Sr dating, illitic clay separates of different size fractions analyzed in two separate batches. First batch were spiked with ${ }^{85} \mathrm{Rb}-{ }^{84} \mathrm{Sr}$ mixed tracer and dissolved in a mixture of distilled HF and $\mathrm{HNO}_{3}$, while the second batch were measured directly by Thermo Xseries 1 quadrupole ICP-MS with precision better than $0.5 \%$ ( $1 \sigma)$. The Sr-enriched fraction was separated using cation exchange resins. $\mathrm{Sr}$ 

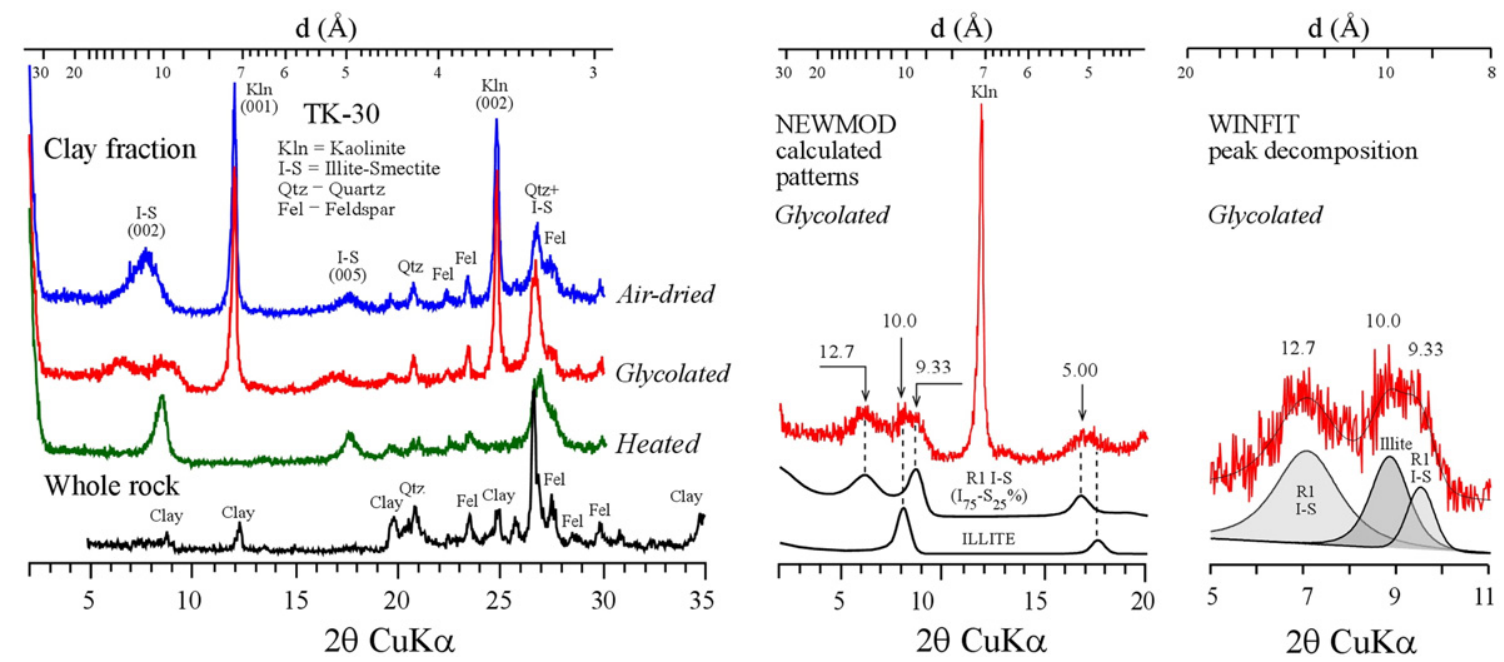

Glycolated

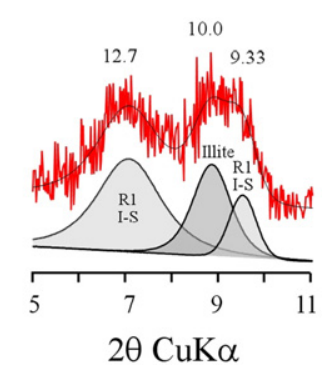

Fig. 6. Kaolinite + I-S assemblages of altered glassy ash tuff (TK-30, Tahtalıkuyu sector, Koru deposit) and analysis of peaks with NEWMOD calculated patterns and WINFIT peak decomposition on glycolated pattern.

isotopic ratios were measured on a VG Sector-54 thermal ionisation mass spectrometer (TIMS) in the Radiogenic Isotope Laboratory at University of Queensland. Sr was loaded in $\mathrm{TaF}_{5}$ and $0.1 \mathrm{~N} \mathrm{H}_{3} \mathrm{PO}_{4}$ on a tantalum or tungsten single filament. $\mathrm{Sr}$ isotopic ratios were corrected for mass discrimination using ${ }^{86} \mathrm{Sr} /{ }^{88} \mathrm{Sr}=0.1194$. Long-term (6 years) reproducibility of statically measured NBS SRM 987 (20; $\mathrm{n}=442)$ is $0.710249 \pm 28$. More recent dynamically measured SRM $987 \mathrm{had}{ }^{86} \mathrm{Sr} /{ }^{88} \mathrm{Sr}$ ratios of $0.710222 \pm 20(2 \sigma ; \mathrm{n}=140) . \mathrm{Rb}-\mathrm{Sr}$ isochron ages were calculated using the ISOPLOT program (Ludwig, 2003).
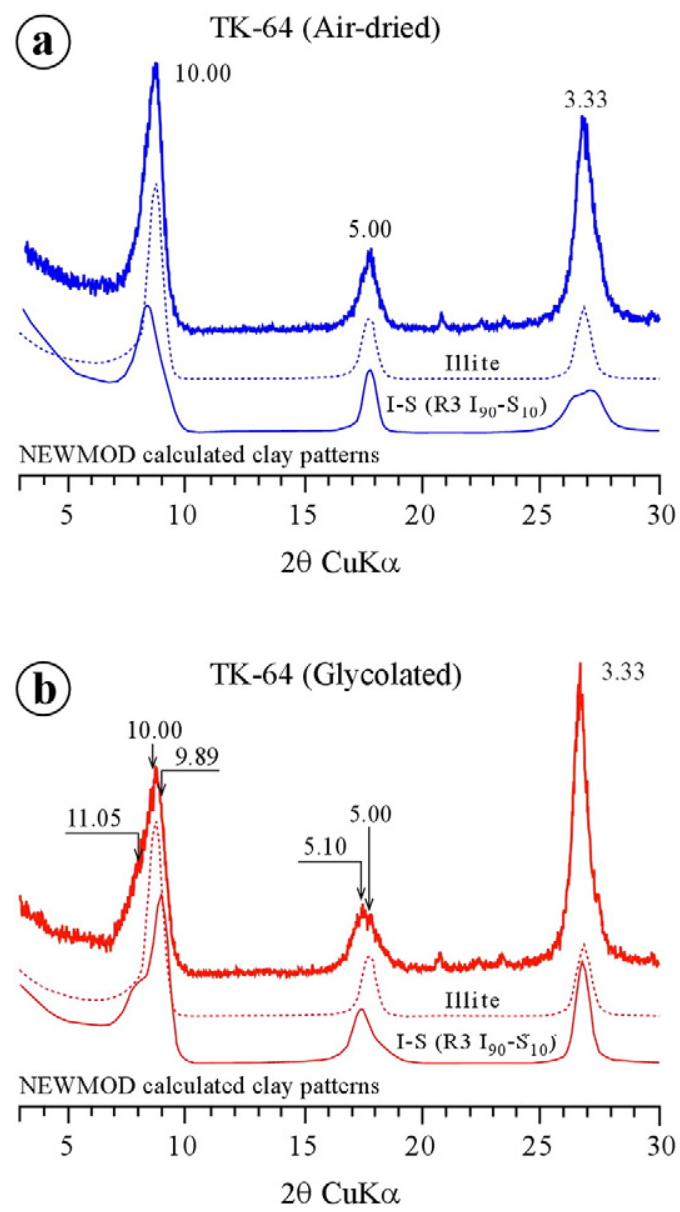

\section{Petrography}

\subsection{Optical microscopy}

Eocene andesites show mostly hypocrystalline, hypohyaline and scarce amygdaloidal textures and contain plagioclase, biotite and hornblende as phenocrysts within a matrix composed of volcanic glass and fine-grained plagioclase microlites. Hydrothermal processes and subsequent weathering effects gave rise to some alterations and

$$
\text { TK-64 (Air-dried) }
$$
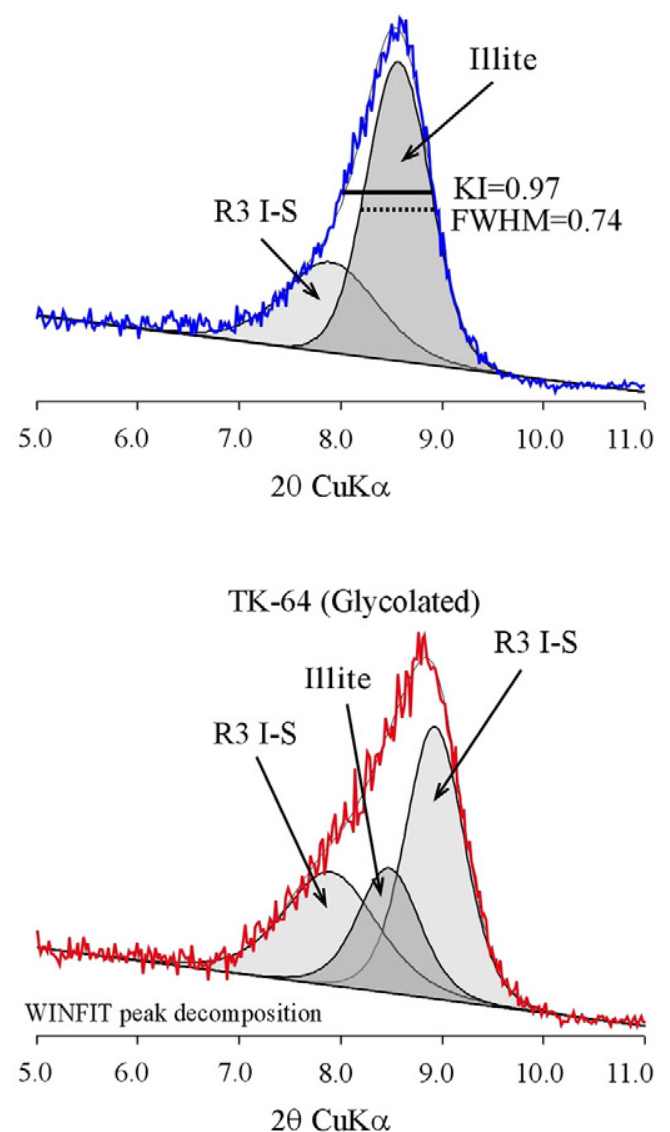

Fig. 7. Analysis of discrete illite and R3 I-S peaks with NEWMOD calculated patterns and WINFIT peak decomposition on the air-dried (a) and glycolated (b) patterns. 
Table 2

Crystal chemical data of illites.

\begin{tabular}{|c|c|c|c|c|c|c|c|c|}
\hline & $(\mathrm{I002}) /(001)$ & $\mathrm{Ir}^{\mathrm{a}}$ & $\mathrm{KI}$ & $d_{060}$ & $2 M_{1}$ & $1 M$ & $1 M_{\mathrm{d}}$ & Th $\left({ }^{\circ} \mathrm{C}\right)^{\mathrm{b}}$ \\
\hline \multicolumn{9}{|c|}{ Koru deposit } \\
\hline TK-64 & 0.29 & 1.89 & 0.97 & 1.5033 & - & 25 & 75 & P: 300, S: 147 \\
\hline KR-186 & 0.54 & 1.19 & 0.39 & & & & & \\
\hline KR-264 & 0.41 & 1.10 & 0.49 & & & & & \\
\hline KR-299 & 0.57 & 1.56 & 0.69 & & & & & \\
\hline EK-25 & 0.25 & 1.05 & 0.45 & & & & & \\
\hline \multicolumn{9}{|c|}{ Tesbihdere deposit } \\
\hline TD-171 & 0.47 & 1.41 & 0.34 & 1.5017 & - & 45 & 55 & P: 275 \\
\hline \multicolumn{9}{|c|}{ Kumarlar deposit } \\
\hline KU-4 & 0.44 & 1.10 & 0.34 & & & & & \\
\hline KU-5 & 0.63 & 1.00 & 0.29 & & & & & \\
\hline KU-6 & 0.43 & 1.77 & 0.31 & 1.5003 & - & 50 & 50 & P: 225 \\
\hline KU-15 & 0.50 & 1.09 & 0.32 & & & & & \\
\hline KU-20 & 0.51 & 1.43 & 0.32 & 1.5013 & 30 & 35 & 35 & P: 278 \\
\hline KU-21 & 0.60 & 1.01 & 0.38 & 1.5015 & 30 & 40 & 30 & P: 278 \\
\hline KU-35 & 0.61 & 1.41 & 0.28 & & & & & \\
\hline
\end{tabular}

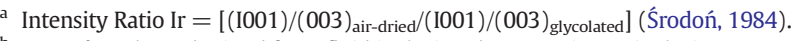

${ }^{b}$ Mean ${ }^{\circ} \mathrm{C}$ values obtained from fluid inclusion data, P: primary inclusions, S: secondary inclusions.

newly formed minerals. In order of abundance, argillization, silicification, iron-oxidization and chloritization were developed within the volcanic glassy mass. In addition to these, argillization, sericitization and chloritization of plagioclase, opacitization and chloritization of hornblende and biotite also occurred.

Oligocene pyroclastic rocks have typical vitroclastic textures, and contain volcanic glass and pumice, volcanogenic plagioclase, sanidine, corroded quartz, biotite and volcanic rock fragments. No detrital components were found in the studied samples. Argillization, sericitization and chloritization were developed within the volcanic glass and pores of the pumice (Bozkaya, 2001). Pyroclastic rocks are mainly represented by agglomerate, lapillistone and tuff with andesite intercalations at the lower parts, silicified rhyolitic breccia at middle parts and silicified rhyolitic tuffs in the upper parts of the sequence. Fine-grained $(<2 \mathrm{~mm})$ pyroclastic rocks (ash tuffs) were classified as mostly glassy tuff and partly lithic and crystal tuffs based on the Schmid (1981) classification (e.g., Bozkaya et al., 2014).

Hydrothermal alteration resulted in silicification (quartz, chalcedony), argillization (kaolinite, illite, I-S and smectite) and Fe(oxyhydroxide)oxidation (Fig. 3a, d, f). Silicification is the most intense type of alteration and developed from the devitrification of volcanic glass and coarse-grained chalcedonic quartz replacement of feldspars in the silicified vitric tuffs. Pure illite-bearing samples have intense sericitization as fine-grained scaly micaceous occurrences within the volcanogenic matrix (Fig. 3c, e, g, h). Kaolinites have developed as

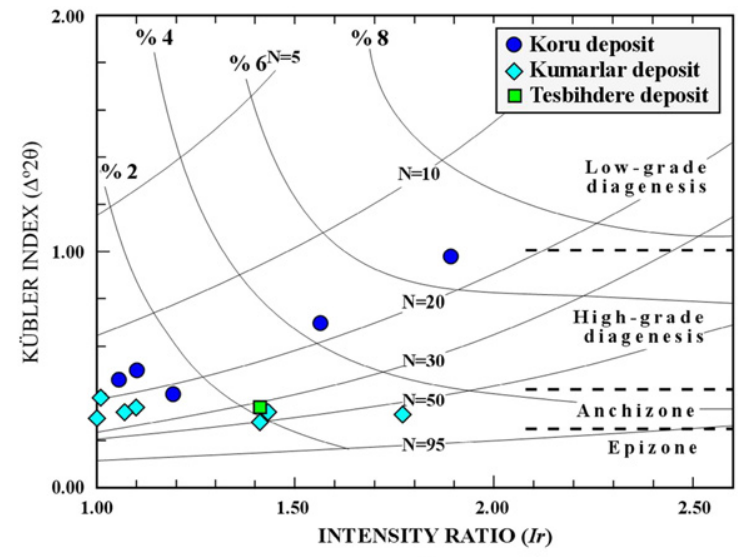

(a) white to gray-colored radial crystals completely covering (Fig. 3b) kaolinite-rich samples, or ellipsoidal pore filling aggregates within the sericitized glassy matrix (Fig. $3 \mathrm{~g}$ ) in kaolinite-poor samples.

\subsection{Scanning electron microscopy}

SEM investigations were undertaken on samples from the argillic zones of the deposits, which contain illite, I-S and kaolinite, as hydrothermal clay minerals (Fig. 4a-f). Illite and I-S (R3) occurrences in relatively low-grade $\left(\sim 150^{\circ} \mathrm{C}\right)$ and/or high grade diagenesis, indicated by fluid inclusion and $\mathrm{KI}\left(\Delta^{\circ} 2 \theta\right)$ data (sample TK-64 from Koru), appear as fine-grained, $\geq 2 \mu \mathrm{m}$, curved flakes and extremely fine-grained fiberlike, $<2 \mu \mathrm{m}$ plumy flakes (Fig. 4a, b). Kaolinites were developed as subhedral and euhedral plates and tightly packed book-like forms within the pores and surrounding fibrous I-S (Fig. 4c). Euhedral alunites are observed as fine-grained crystals, $\sim 5 \mu \mathrm{m}$, which are surrounded by kaolinite and I-S crystals. Their morphology and interrelations with other minerals suggest that the I-S and kaolinite, as well as alunite, have a completely neo-crystallized origin. Euhedral to subhedral illites were developed as extremely coarse-grained plates, up to $20 \mu \mathrm{m}$, in the high grade, $275^{\circ} \mathrm{C}$ and/or anchimetamorphic, based on fluid inclusion and $\mathrm{KI}\left(\Delta^{\circ} 2 \theta\right)$ data, respectively (sample (TD-171) from Tesbihdere (Fig. 4d). The larger crystal sizes of illites appear related to the higher grade of formation, rather than inheritance from volcanogenic primary micas or detrital input from other sources. The other sample (KU-5) of

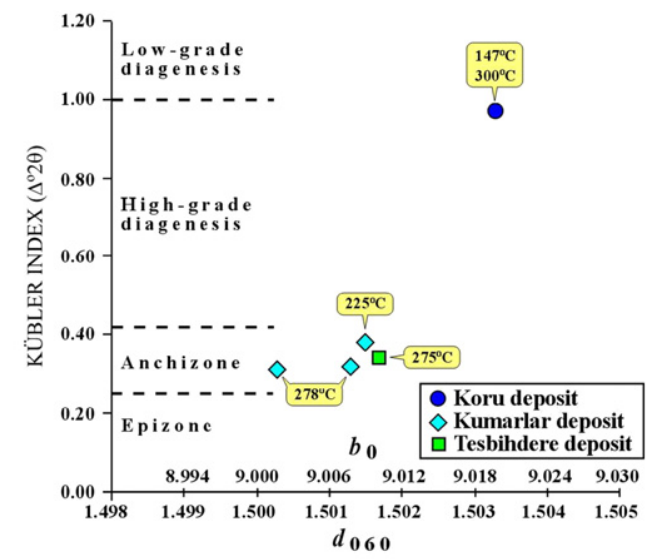

(b)

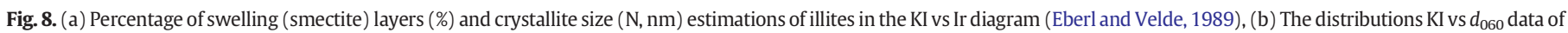
illites. Temperature values were obtained from fluid inclusion data as presented in Table 2 . 
Table 3

Major oxide composition of illites and volcanic host-rocks.

\begin{tabular}{|c|c|c|c|c|c|c|c|c|}
\hline \multirow[t]{2}{*}{$\%$ oxide } & \multicolumn{6}{|l|}{ Illite } & \multirow{2}{*}{$\frac{\text { Rhyodacite }}{\text { KR-322 }}$} & \multirow{2}{*}{$\frac{\text { Dacite }}{\text { KR-247 }}$} \\
\hline & KU-6 & KU-20 & KU-21 & TK-64 & TD-171 & Ulubey $^{\mathrm{a}}$ & & \\
\hline $\mathrm{SiO}_{2}$ & 48.02 & 48.28 & 48.83 & 46.85 & 47.61 & 49.96 & 62.88 & 64.08 \\
\hline $\mathrm{TiO}_{2}$ & 0.943 & 0.498 & 0.953 & 0.912 & 0.933 & 0.22 & 0.56 & 0.45 \\
\hline $\mathrm{Al}_{2} \mathrm{O}_{3}$ & 36.26 & 32.74 & 35.38 & 35.95 & 36.21 & 32.14 & 18.42 & 18.03 \\
\hline $\mathrm{Fe}_{2} \mathrm{O}_{3}(\mathrm{t})$ & 0.69 & 2.42 & 0.58 & 1.47 & 0.83 & 0.84 & 3.56 & 3.22 \\
\hline $\mathrm{MnO}$ & 0.004 & 0.017 & 0.022 & 0.025 & 0.007 & n.a. & 0.08 & 0.18 \\
\hline $\mathrm{MgO}$ & 0.38 & 1.96 & 0.38 & 0.38 & 0.36 & 1.16 & 1.88 & 1.26 \\
\hline $\mathrm{CaO}$ & 0.02 & 0.15 & 0.02 & 0.01 & 0.02 & 0.82 & 3.27 & 1.33 \\
\hline $\mathrm{Na}_{2} \mathrm{O}$ & 0.72 & 0.94 & 0.55 & 0.65 & 0.72 & 0.54 & 3.57 & 5.46 \\
\hline $\mathrm{K}_{2} \mathrm{O}$ & 6.86 & 6.71 & 6.84 & 6.64 & 7.18 & 7.50 & 4.48 & 4.39 \\
\hline $\mathrm{P}_{2} \mathrm{O} 5$ & 0.12 & 0.14 & 0.10 & 0.13 & 0.13 & n.a. & 0.13 & 0.10 \\
\hline LOI & 6.25 & 6.61 & 6.84 & 7.05 & 6.16 & 6.36 & 2.15 & 2.19 \\
\hline Total & 100.25 & 100.46 & 100.49 & 100.05 & 100.16 & 99.54 & 100.90 & 100.69 \\
\hline $\mathrm{Si}$ & 3.14 & 3.20 & 3.20 & 3.11 & 3.13 & 3.31 & & \\
\hline $\mathrm{Al}$ & 0.86 & 0.80 & 0.80 & 0.89 & 0.87 & 0.69 & & \\
\hline TC & 0.86 & 0.80 & 0.80 & 0.89 & 0.87 & 0.69 & & \\
\hline $\mathrm{Al}$ & 1.94 & 1.75 & 1.93 & 1.92 & 1.93 & 1.82 & & \\
\hline $\mathrm{Ti}$ & 0.05 & 0.02 & 0.05 & 0.05 & 0.05 & 0.01 & & \\
\hline $\mathrm{Fe}^{3+}$ & 0.03 & 0.12 & 0.03 & 0.07 & 0.04 & 0.04 & & \\
\hline $\mathrm{Mg}$ & 0.04 & 0.19 & 0.04 & 0.04 & 0.04 & 0.11 & & \\
\hline OC & 0.19 & 0.10 & 0.15 & 0.21 & 0.18 & 0.13 & & \\
\hline TOC & 2.06 & 2.09 & 2.05 & 2.08 & 2.05 & 1.99 & & \\
\hline $\mathrm{Ca}$ & 0.00 & 0.01 & 0.00 & 0.00 & 0.00 & 0.06 & & \\
\hline $\mathrm{Na}$ & 0.09 & 0.12 & 0.07 & 0.08 & 0.09 & 0.07 & & \\
\hline K & 0.57 & 0.57 & 0.57 & 0.56 & 0.60 & 0.63 & & \\
\hline ILC & 0.67 & 0.71 & 0.64 & 0.65 & 0.70 & 0.82 & & \\
\hline TLC & 0.67 & 0.71 & 0.64 & 0.65 & 0.70 & 0.82 & & \\
\hline
\end{tabular}

$\mathrm{Fe}_{2} \mathrm{O}_{3}(\mathrm{t})$ : total iron, LOI: loss on ignition, TC: tetrahedral charge, TOC: total octahedral cation, OC: octahedral charge, ILC: interlayer charge, TLC: total layer charge, n.a.: not analyzed.

a Hydrothermal illite from NE Pontides, Turkey (Celik et al., 1999).

similar high grade, $280{ }^{\circ} \mathrm{C}$ and/or anchimetamorphic, has euhedral kaolinite or dickite as loosely stacked aggregates or booklets, together with euhedral quartz within the pores (Fig. 4e), indicating they developed in situ from hydrothermal fluids. Illites have a similar morphology in sample TD-171, with coarse-grained, up to $10 \mu \mathrm{m}$, subhedral plates or flakes (Fig. 4f).

\subsection{Mineralogy}

Based on optical microscopy and X-ray diffraction analysis, the alteration products of the volcanic and pyroclastic rocks are quartz, kaolinite, illite, mixed-layer illite-smectite (I-S) and chlorite-smectite (C-S) and smectite (Table 1, Bozkaya et al., 2007). Illite and kaolinite form a pure clay fraction as well as contributing to the clay mineral associations (Figs. 5 and 6), such as kaolinite + illite, kaolinite + illite + I-S and kaolinite + illite + I-S + smectite.

Illite and smectite contents and ordering types (Reichweite, R) of I-S were estimated by comparing, with NEWMOD, calculated patterns and the peak decomposition method with the WINFIT program. In sample

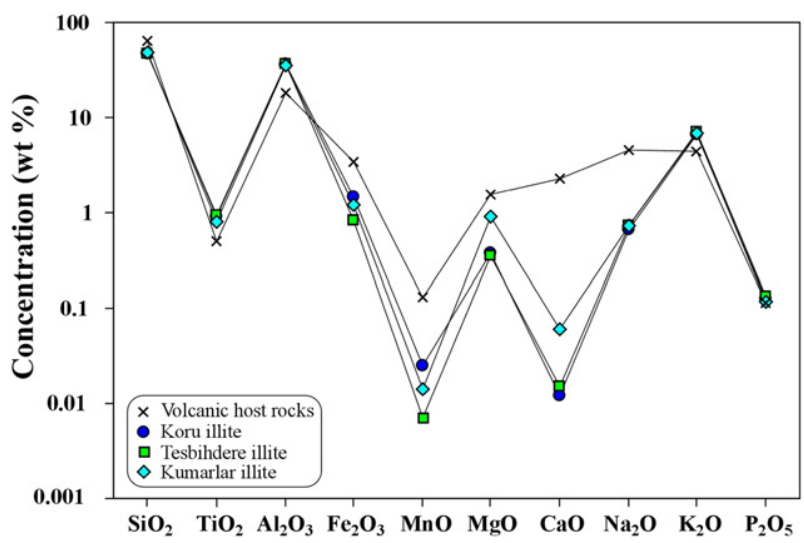

Fig. 9. Distribution of major oxide composition (wt.\%) of illites and volcanic host-rocks.
TK-30 from Koru, that includes illite + I-S and kaolinite, I-S has R1 type ordering with a $75 \%$ illite and $25 \%$ smectite content (Fig. 6). In the another sample (TK-64) from the same deposit, analysis of the illite composite peak near $10 \AA$ by comparing the calculated clay patterns with the experimental pattern showed that the high peak width $\left(\Delta^{\circ} 2 \theta=0.97\right)$ is related to wideness effect of I-S ( $\mathrm{R} 3$ type with $90 \%$ illite and $10 \%$ smectite) peak (Fig. 7 ).

KI values of illites, change from 0.28 to $0.97 \Delta^{\circ} 2 \theta$, indicating highgrade diagenesis for the Koru deposit, whereas for the Tesbihdere and Kumarlar deposits the grade is anchimetamorphic (Table 2, Fig. 8a, b). The percentages of swelling layers in most of illites is below $2 \%$, except for three samples, which have approximately 3 and $7 \%$. The crystallite sizes of illites are distributed between 15 and $55 \mathrm{~nm}$, but are predominantly between 20 and $50 \mathrm{~nm}$ (Fig. 8a). The $d_{060}$ values of illites are between 1.5003-1.5033 $\AA$, mean $1.5016 \AA$, indicating a dioctahedral composition, as octahedral $\mathrm{Fe}+\mathrm{Mg}$ are between 0.19 and 0.53 atoms per formula unit (a.p.f.u.), with a mean of 0.33 a.p.f.u. Homogenization temperatures from fluid inclusions within the sphalerites and quartz in the samples (Table 2, Fig. 8b) seem to be consistent with the possible conditions derived from the KI data (e.g., $~ 100-200{ }^{\circ} \mathrm{C}$ interval for high-grade diagenetic, and $\sim 200-300{ }^{\circ} \mathrm{C}$ interval for the anchizone, defined by the KI values of illites; Frey et al., 1980; Merriman and Frey, 1999).

Polytypes of illite are represented by $2 M_{1}, 1 M$ and $1 M_{\mathrm{d}} .1 M$, with the $1 M_{d}$ polytype dominant for all illites, except from Kumarlar deposit where $2 M_{1}$ is dominant (see Table 2, and Fig. 5). The appearance of the $2 M_{1}$ polytype may be related to the higher grades (anchizone) rather than an inheritance from detrital micas in the volcanics, although some samples did not contain the $2 M_{1}$ polytype despite of the higher, anchizonal grade.

\subsection{Geochemistry}

\subsubsection{Major elements}

Major element compositions of illites, volcanic host-rocks (rhyolite and rhyodacite) from the study area and hydrothermal illite from the Ulubey area of the Eastern Pontides (Celik et al., 1999), for comparison, 
Table 4

Trace and REE contents (ppm) of illite samples with different grain sizes.

\begin{tabular}{|c|c|c|c|c|c|c|c|c|}
\hline & \multirow{2}{*}{$\frac{\text { KR-253 }}{\text { Whole rock }}$} & \multicolumn{2}{|l|}{ KU-6 } & \multicolumn{2}{|l|}{ TK-64 } & \multicolumn{3}{|l|}{ TD-171 } \\
\hline & & $1-2 \mu \mathrm{m}$ & $<1 \mu \mathrm{m}$ & $1-2 \mu \mathrm{m}$ & $<1 \mu \mathrm{m}$ & $1-2 \mu \mathrm{m}$ & $0.5-1 \mu \mathrm{m}$ & $<0.5 \mu \mathrm{m}$ \\
\hline $\mathrm{Ti}$ & 3957.0 & 863.48 & 595.53 & 4447.19 & 2165.14 & 1158.09 & 811.52 & 637.94 \\
\hline $\mathrm{Ca}$ & 1343.6 & 1341.02 & 1562.13 & 1952.37 & 2383.69 & 760.50 & 635.94 & 937.76 \\
\hline $\mathrm{P}$ & 698.0 & 628.80 & 718.97 & 515.99 & 769.77 & 320.67 & 318.67 & 484.93 \\
\hline $\mathrm{Cr}$ & $<20.0$ & 6.18 & 6.20 & 14.20 & 18.97 & 4.92 & 3.61 & 3.94 \\
\hline $\mathrm{Ni}$ & $<20.0$ & 2.50 & 1.99 & 4.20 & 4.25 & 1.83 & 1.12 & 1.75 \\
\hline Co & $<10.0$ & 5.73 & 7.52 & 5.02 & 5.47 & 7.24 & 8.18 & 10.82 \\
\hline Sc & n.a. & 7.21 & 8.41 & 21.87 & 34.28 & 7.71 & 7.99 & 7.44 \\
\hline $\mathrm{V}$ & 78.00 & 59.56 & 69.25 & 228.05 & 405.11 & 126.55 & 142.67 & 129.38 \\
\hline $\mathrm{Cu}$ & $<10.0$ & 164.17 & 93.48 & 234.31 & 38.70 & 32.66 & 27.90 & 34.94 \\
\hline $\mathrm{Pb}$ & 12.0 & 5609.93 & 3218.25 & 1967.05 & 1840.18 & 71.29 & 43.07 & 52.91 \\
\hline $\mathrm{Zn}$ & 153.0 & 216.83 & 279.38 & 4489.58 & 3595.22 & 30.22 & 28.38 & 37.04 \\
\hline $\mathrm{Cd}$ & n.a. & 0.35 & 0.41 & 6.80 & 1.72 & 0.06 & 0.05 & 0.05 \\
\hline Sn & 2.0 & 1.76 & 2.01 & 2.79 & 3.04 & 3.35 & 3.63 & 3.26 \\
\hline W & 195 & 56.19 & 33.55 & 43.56 & 13.57 & 89.58 & 63.15 & 61.38 \\
\hline Mo & $<2.0$ & 2.68 & 1.66 & 1.78 & 1.06 & 2.46 & 1.62 & 1.74 \\
\hline $\mathrm{Rb}$ & 98.0 & 427.47 & 486.20 & 466.79 & 666.43 & 231.12 & 261.99 & 249.30 \\
\hline Cs & 3.9 & 34.16 & 49.79 & 27.78 & 47.90 & 3.73 & 3.42 & 3.94 \\
\hline $\mathrm{Ba}$ & 1170.0 & 1475.21 & 999.67 & 698.76 & 156.55 & 601.38 & 707.19 & 644.24 \\
\hline $\mathrm{Sr}$ & 225 & 46.53 & 58.74 & 43.25 & 44.28 & 222.81 & 232.10 & 296.28 \\
\hline $\mathrm{Tl}$ & 0.11 & 8.81 & 10.22 & 3.24 & 3.76 & 1.57 & 1.77 & 1.72 \\
\hline $\mathrm{Ga}$ & 16 & 20.37 & 23.64 & 34.54 & 55.80 & 30.69 & 33.17 & 32.99 \\
\hline $\mathrm{Li}$ & n.a. & 6.83 & 4.05 & 9.82 & 12.86 & 2.88 & 2.20 & 1.88 \\
\hline Тa & 0.86 & 0.62 & 0.39 & 0.81 & 0.44 & 0.96 & 0.58 & 0.47 \\
\hline $\mathrm{Nb}$ & 10.9 & 3.90 & 2.22 & 8.93 & 4.76 & 4.46 & 1.92 & 1.13 \\
\hline $\mathrm{Hf}$ & 5.5 & 2.30 & 3.04 & 5.19 & 6.25 & 5.58 & 5.85 & 5.01 \\
\hline $\mathrm{Zr}$ & 213 & 69.19 & 91.19 & 194.10 & 225.78 & 202.00 & 213.40 & 180.14 \\
\hline $\mathrm{Y}$ & 33.40 & 11.97 & 15.06 & 26.04 & 30.47 & 25.88 & 23.13 & 19.74 \\
\hline Th & 14.80 & 15.66 & 15.76 & 18.61 & 21.78 & 19.78 & 19.97 & 18.46 \\
\hline $\mathrm{U}$ & 3.49 & 3.99 & 4.94 & 5.95 & 6.73 & 6.91 & 7.52 & 6.54 \\
\hline $\mathrm{La}$ & 34.20 & 27.96 & 10.03 & 35.65 & 36.38 & 30.93 & 17.60 & 12.34 \\
\hline $\mathrm{Ce}$ & 63.30 & 50.58 & 17.62 & 81.00 & 82.95 & 53.52 & 31.10 & 22.82 \\
\hline $\operatorname{Pr}$ & 6.80 & 5.22 & 1.93 & 6.91 & 7.03 & 5.46 & 3.22 & 2.42 \\
\hline $\mathrm{Nd}$ & 26.60 & 17.26 & 6.57 & 23.97 & 24.30 & 18.34 & 10.94 & 8.48 \\
\hline $\mathrm{Sm}$ & 5.19 & 2.67 & 1.19 & 4.75 & 4.87 & 3.30 & 2.12 & 1.69 \\
\hline $\mathrm{Eu}$ & 1.28 & 0.47 & 0.26 & 1.75 & 1.83 & 0.83 & 0.53 & 0.38 \\
\hline Gd & 5.11 & 1.93 & 1.40 & 4.44 & 4.64 & 3.17 & 2.26 & 1.90 \\
\hline $\mathrm{Tb}$ & 0.85 & 0.30 & 0.29 & 0.75 & 0.82 & 0.57 & 0.45 & 0.38 \\
\hline Dy & 4.74 & 1.87 & 2.17 & 4.68 & 5.33 & 3.95 & 3.34 & 2.88 \\
\hline Ho & 1.02 & 0.43 & 0.53 & 0.97 & 1.11 & 0.91 & 0.81 & 0.71 \\
\hline $\mathrm{Er}$ & 3.14 & 1.38 & 1.75 & 2.70 & 3.15 & 2.87 & 2.68 & 2.36 \\
\hline $\mathrm{Tm}$ & 0.47 & 0.24 & 0.31 & 0.41 & 0.48 & 0.49 & 0.47 & 0.41 \\
\hline $\mathrm{Yb}$ & 2.97 & 1.71 & 2.25 & 2.66 & 3.07 & 3.43 & 3.40 & 2.92 \\
\hline $\mathrm{Lu}$ & 0.47 & 0.27 & 0.35 & 0.37 & 0.43 & 0.53 & 0.54 & 0.46 \\
\hline
\end{tabular}

are presented in Table 3. Different illites are compositionally similar with only minor variability but are distinctly different to the composition of the volcanic rocks (Fig. 9). The illite compositions are also similar to those from the Ulubey area, which has slightly lower concentrations of $\mathrm{Al}$ and Ti with higher concentrations of $\mathrm{Mg}$ and $\mathrm{Ca}$. The structural formulas of illites were calculated based on 22 negative charges, matched to 10 oxide and 2 hydroxide ions (Weaver and Pollard, 1973). Illites have tetrahedral substitutions of $0.80-0.89$ atoms of $\mathrm{Al}$ for $\mathrm{Si}$, octahedral substitutions of 0.03-0.12 atoms of Fe and 0.04-0.19 atoms of $\mathrm{Mg}$ for $\mathrm{Al}$ (Table 3). The total octahedral cation numbers are slightly higher than 2.00 (2.05-2.09). The dominant interlayer cation is $\mathrm{K}, 0.56-0.60$ atoms; $\mathrm{Na}$ is the other interlayer cation, 0.07-0.12
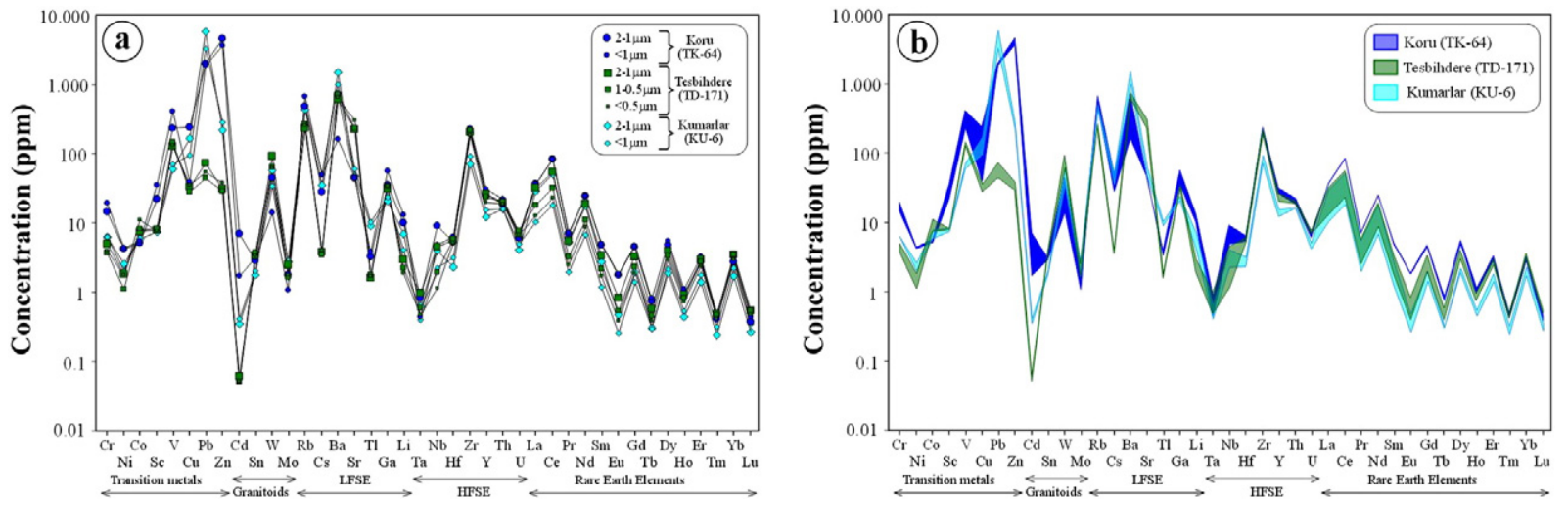

Fig. 10. Distribution of trace element composition of illites with different grain sizes. 

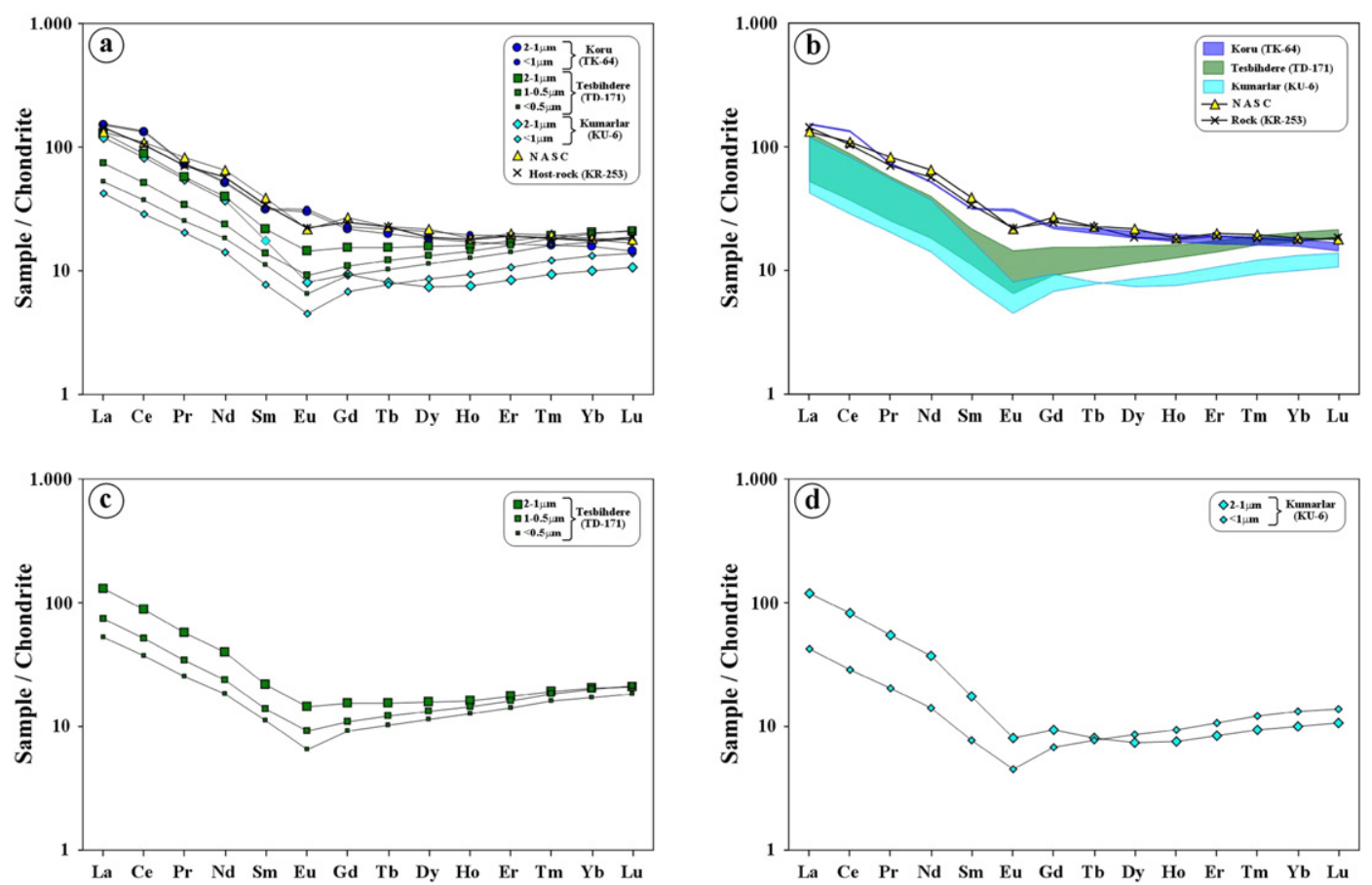

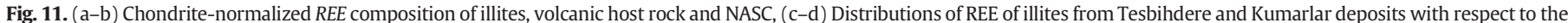
different grain sizes.

atoms. The average structural formulas of illites from the different deposits are given below:

Koru $\left(\mathrm{K}_{0.56} \mathrm{Na}_{0.08}\right)\left(\mathrm{Al}_{1.92} \mathrm{Fe}_{0.07} \mathrm{Mg}_{0.04} \mathrm{Ti}_{0.05}\right)\left(\mathrm{Si}_{3.11} \mathrm{Al}_{0.89} \mathrm{O}_{10}\right)(\mathrm{OH})_{2} \cdot 2 \mathrm{H}_{2} \mathrm{O}$ Tesbihdere $\left(\mathrm{K}_{0.60} \mathrm{Na}_{0.09}\right)\left(\mathrm{Al}_{1.93} \mathrm{Fe}_{0.04} \mathrm{Mg}_{0.04} \mathrm{Ti}_{0.05}\right)\left(\mathrm{Si}_{3.13} \mathrm{Al}_{0.87} \mathrm{O}_{10}\right)(\mathrm{OH})_{2} \cdot 2 \mathrm{H}_{2} \mathrm{O}$ Kumarlar $\left(\mathrm{K}_{0.57} \mathrm{Na}_{0.09}\right)\left(\mathrm{Al}_{1.87} \mathrm{Fe}_{0.06} \mathrm{Mg}_{0.09} \mathrm{Ti}_{0.04}\right)\left(\mathrm{Si}_{3.18} \mathrm{Al}_{0.82} \mathrm{O}_{10}\right)(\mathrm{OH})_{2} \cdot 2 \mathrm{H}_{2} \mathrm{O}$.

\subsubsection{Trace and REEs}

Trace element and REE concentrations of illites from Koru, Kumarlar and Tesbihdere with a whole rock sample from Koru are presented in Table 4. Different size fractions have been analyzed from three deposits and the elemental concentrations in each show no obvious significant differences. There are differences in elemental concentrations between deposits that may be related to the mineralization in the deposits. The base-metal deposits of Koru and Kumarlar have high concentrations of $\mathrm{Cu}, \mathrm{Pb}, \mathrm{Zn}, \mathrm{Cd}$ compared with Tesbihdere where there is much less galena, sphalerite and chalcopyrite. Concentration of these metals are also significantly higher than that in the host rock from Koru indicating the high concentrations are unlikely to be from the host rock but rather derived from the mineralizing fluid. Other differences between the deposits can be seen in the spider diagrams (Fig. 10a, b). All illites are enriched in REE compared to chondrite, but except for Koru are depleted relative the North American Shale composite (NASC). The chondrite normalized REE patterns and abundances for both clay size fractions from Koru match those of the Koru whole rock and are identical to NASC except for the positive europium anomaly of the illites (Fig. 11a, b). Illites from the other deposits have lower chondrite normalized

Table 5

Oxygen and hydrogen isotope composition of illites and quartz from the Koru and Kumarlar deposits.

\begin{tabular}{lllcl}
\hline Sample no & Deposit & Mineral & $\delta{ }^{18}$ O \% SMOW & $\delta$ D \% SMOW \\
\hline TK-64 & Koru & Illite + I-S & 7.6 & -88.8 \\
KU-21 & Kumarlar & Illite & 3.1 & -89.1 \\
TK-53-1 & Koru & Quartz & 14.2 & -88.0
\end{tabular}

abundances, negative europium anomalies with HREE enrichment compared to the samples from Koru. REE abundances and the level of HREE enrichment are greater for samples from Tesbihdere than those from Kumarlar. Different illite size fractions from Tesbihdere and Kumarlar show lower REE concentration with decreasing illite size fraction, which is greatest for the LREE and least or non-existent for the HREE (Fig. 11c, d). The different size fractions from Koru are identical with no reduction in either LREE or HREE.

\subsubsection{Stable isotopes}

The oxygen and hydrogen isotope analyses of two illites from Koru and Kumarlar are presented in Table 5 . The $\delta D$ values are similar, but the $\delta^{18} \mathrm{O}$ values are $4.5 \%$ o different. The isotopic distribution of illites

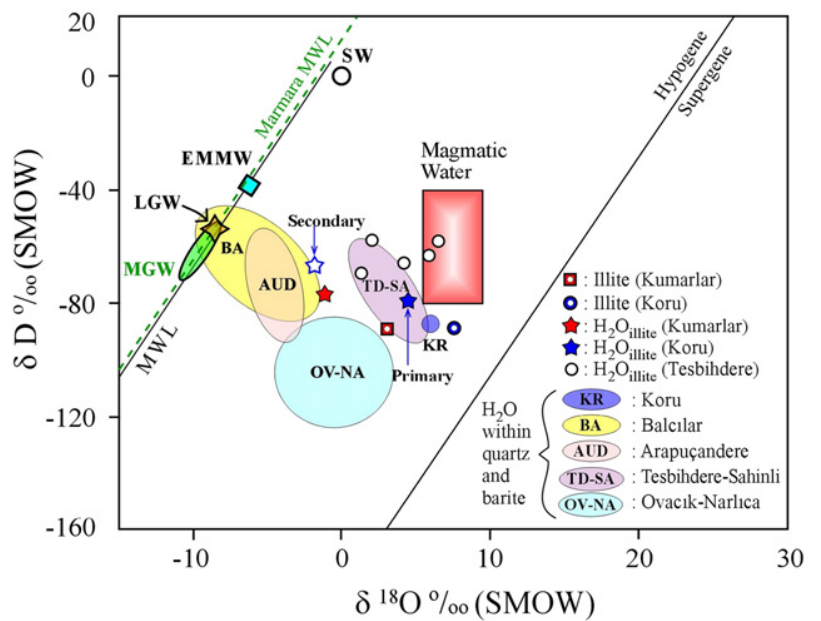

Fig. 12. Distribution of oxygen and hydrogen isotope values of illites (Tesbihdere illites from Yilmaz et al., 2010). Fluid compositional areas, obtained from fluids trapped in hydrothermal quartz and barite crystals from Koru, Balcilar (Bozkaya and Gokce, 2007), Arapucandere (Bozkaya and Banks, 2015), Tesbihdere-Sahinli (Yilmaz et al., 2010), Ovacik-Narlica (Yilmaz, 2002) deposits, were also shown for comparison. MWL: Meteoric Water Line, MGW: Marmara Geothermal Water, 

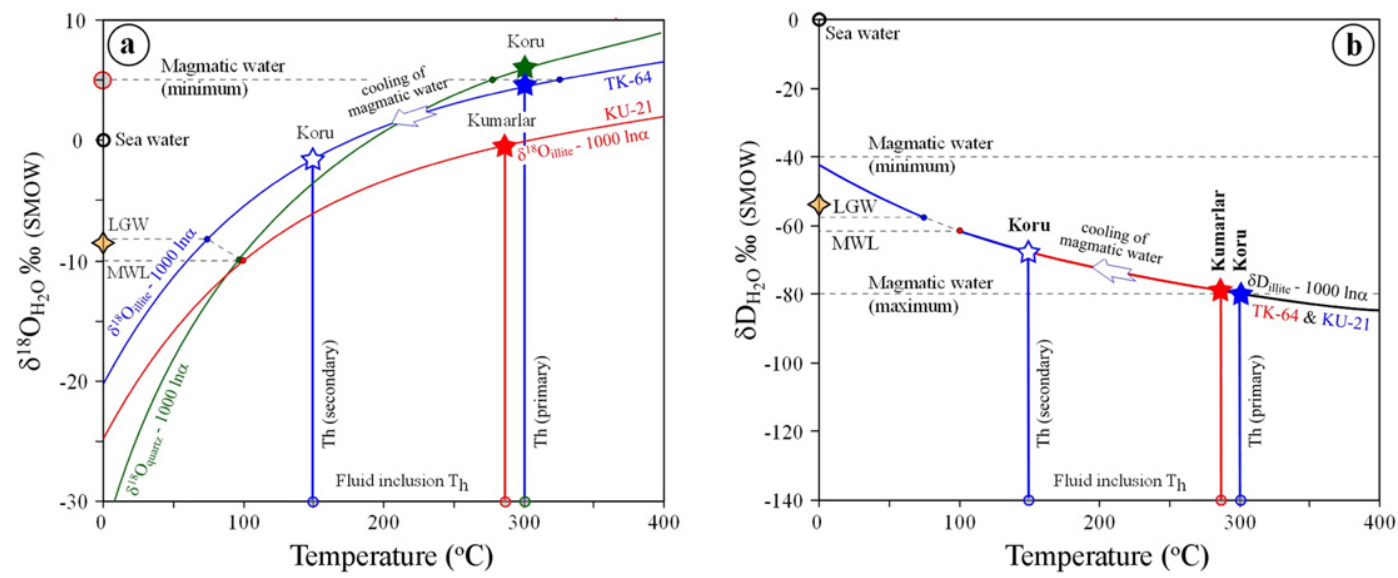

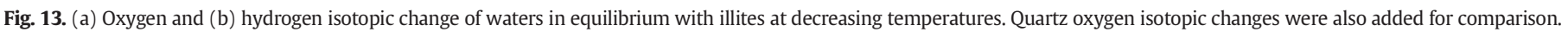

and water composition are presented in Fig. 12, together with the lines of meteoric water (Craig, 1961) and supergene-hypogene (Sheppard et al., 1969).

The calculated isotopic ratios of fluids in equilibrium with illitewater fractionation factors (Savin and Lee, 1988 for $\delta^{18} \mathrm{O}$; Yeh, 1980 for $\delta D$ ) show that illite-forming fluids evolve toward more positive $\delta^{18} \mathrm{O}$ and more negative $\delta \mathrm{D}$ values with increasing temperature. The calculation of the fractionation factors for illites in the Koru (TK-64) and Kumarlar (KU-21) samples used the average values for homogenization temperatures $\left(300{ }^{\circ} \mathrm{C}\right.$ and $147^{\circ} \mathrm{C}$ for TK-64, $278{ }^{\circ} \mathrm{C}$ for KU-21) of fluid inclusions in sphalerite and quartz. The initial water compositions correspond to the local geothermal water composition of Biga Peninsula (LGW, $\delta^{18} \mathrm{O}=-8.5 \%$, $\delta \mathrm{D}=-54 \%, \mathrm{~T}^{\circ} \mathrm{C}=46.3$, Yilmaz et al., 2010) or Marmara (MGW, Eisenlohr, 1997) rather than Eastern Mediterranean Meteoric Water $\left(\delta^{18} \mathrm{O}=\sim 6.12 \%\right.$, $\delta \mathrm{D}=\sim 37.96 \%$, Gat et al., 1996) (Fig. 12). Modeling this water as it evolved to higher temperature, using the equation of Yeh (1980), intersects the measured $\delta \mathrm{D}$ and $\delta^{18} \mathrm{O}$ values of the illites from Koru and Kumarlar. The temperature of the water in equilibrium with the illites from both deposits corresponds closely to the high temperature fluid inclusions homogenization temperatures (Fig. 12). The model $\delta \mathrm{D}$ and $\delta^{18} \mathrm{O}$ fluid evolution coincides with the ore-forming fluid compositions from quartz in the main base-metal ore deposits at Balcilar, Arapucandere and Tesbihdere but not the Ovacik-Narlica deposits (Yilmaz et al., 2007, 2010; Bozkaya and Banks, 2014) where the fluid inclusion waters plot at lower $\delta \mathrm{D}$ values. The isotopic compositions of the majority of the fluid inclusion waters plot, to variable extents, away from magmatic water box, thus the origin of hydrothermal fluids might seem to be local meteoric (or geothermal) water that shifted to more positive $\delta^{18} \mathrm{O}$ and more negative $\delta \mathrm{D}$ compositions due to fluid-rock isotopic exchange as the temperature increased (Figs. 12 and 13). This is not the case as it would imply a number if different generations of illite with the last being the high temperature generation. It would also suggest that trapping of fluid inclusions in quartz would show higher homogenization temperatures in the later generations. The data from Koru and Kumarlar shows the opposite with lower temperatures in later generations. A similar

Table 6

$\mathrm{Rb}-\mathrm{Sr}$ isotope data for different sized illites from the studied ore deposits.

\begin{tabular}{lccccc}
\hline Sample & Size fraction $(\mu \mathrm{m})$ & $\mathrm{Rb}(\mathrm{ppm})$ & $\mathrm{Sr}(\mathrm{ppm})$ & ${ }^{87} \mathrm{Rb} /{ }^{86} \mathrm{Sr}$ & ${ }^{87} \mathrm{Sr} /{ }^{86} \mathrm{Sr} \pm 2 \sigma$ \\
\hline KU-6 & $2-1$ & 691.8 & 65.41 & 30.62 & $0.716036 \pm 7$ \\
KU-6 & $<1$ & 783.3 & 82.56 & 27.46 & $0.714912 \pm 7$ \\
TK-64 & $2-1$ & 751.7 & 60.75 & 35.83 & $0.719018 \pm 9$ \\
TK-64 & $<1$ & 1066 & 62.32 & 49.55 & $0.723092 \pm 7$ \\
TD-171 & $2-1$ & 323.8 & 312.5 & 2.997 & $0.708129 \pm 8$ \\
TD-171 & $1-0.5$ & 365.8 & 325.3 & 3.254 & $0.708123 \pm 5$ \\
TD-171 & $<0.5$ & 348.8 & 415.2 & 2.430 & $0.707770 \pm 6$ \\
\hline
\end{tabular}

progression from high to low temperatures was reported at Tesbihdere and Arapucandere (Bozkaya et al., 2014; Bozkaya and Banks, 2015) which are located in the same region and are of a comparable style of mineralization. Cooling of the initial high temperature fluid in equilibrium with illite would be compatible with the fluid inclusion evidence and would imply that the local geothermal waters contain a significant magmatic fluid component and are not just heated by the magmatism. However, we might also expect to find different illite generations with their $\delta \mathrm{D}$ and $\delta^{18} \mathrm{O}$ composition reflecting a formation at lower temperatures. That we have only two samples from the areas that would have seen the highest temperature magmatic fluids, it is not surprising we find only one generation of illite. It may be possible that different generations of illites were formed away from the main upwelling zone by cooler fluids with a resultant change in $\delta \mathrm{D}$ and $\delta^{18} \mathrm{O}$ in line with the predicted isotopic fractionation at lower temperatures. The conventional interpretation in this style of mineralization is that data plotting between the magmatic box and meteoric water line represents a mixture of these two fluids and in many cases this is true. However, in the deposits mentioned here from the Biga Peninsula the fluid inclusion data, although showing cooling, does not show an associated lowering of salinity as would be expected on mixing these two fluids. In these cases cooling is due to fluctuations in pressure during vein opening and not by fluid mixing (Bozkaya and Banks, 2015). It is noticeable that the geothermal waters do not plot with the value for meteoric water for non-geothermal areas (Eisenlohr, 1997) but at more negative

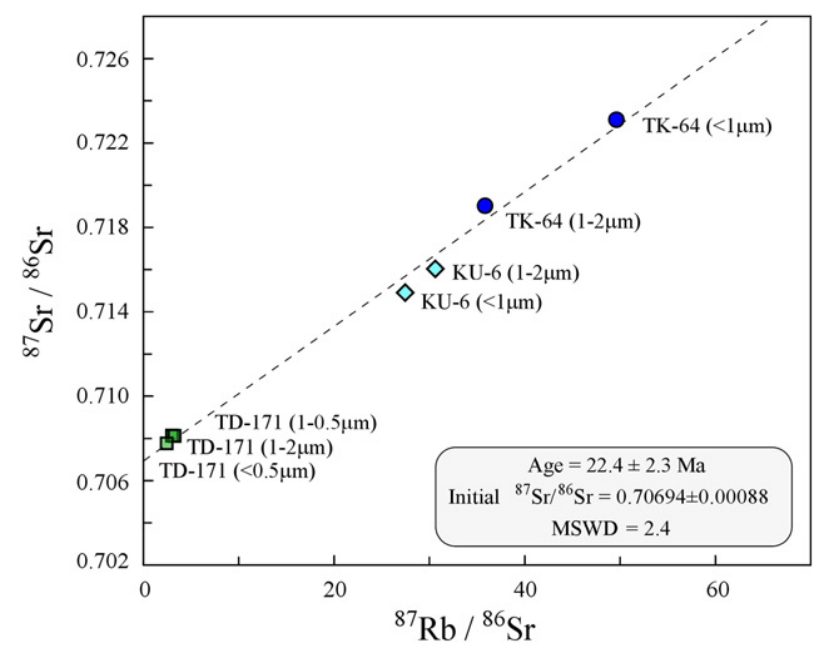

Fig. 14. $\mathrm{Rb}-\mathrm{Sr}$ isochron diagrams for illites with different sizes from ore deposits (Different labels of the samples indicate different deposits; TK: Koru, KU: Kumarlar, TD: Tesbihdere). 


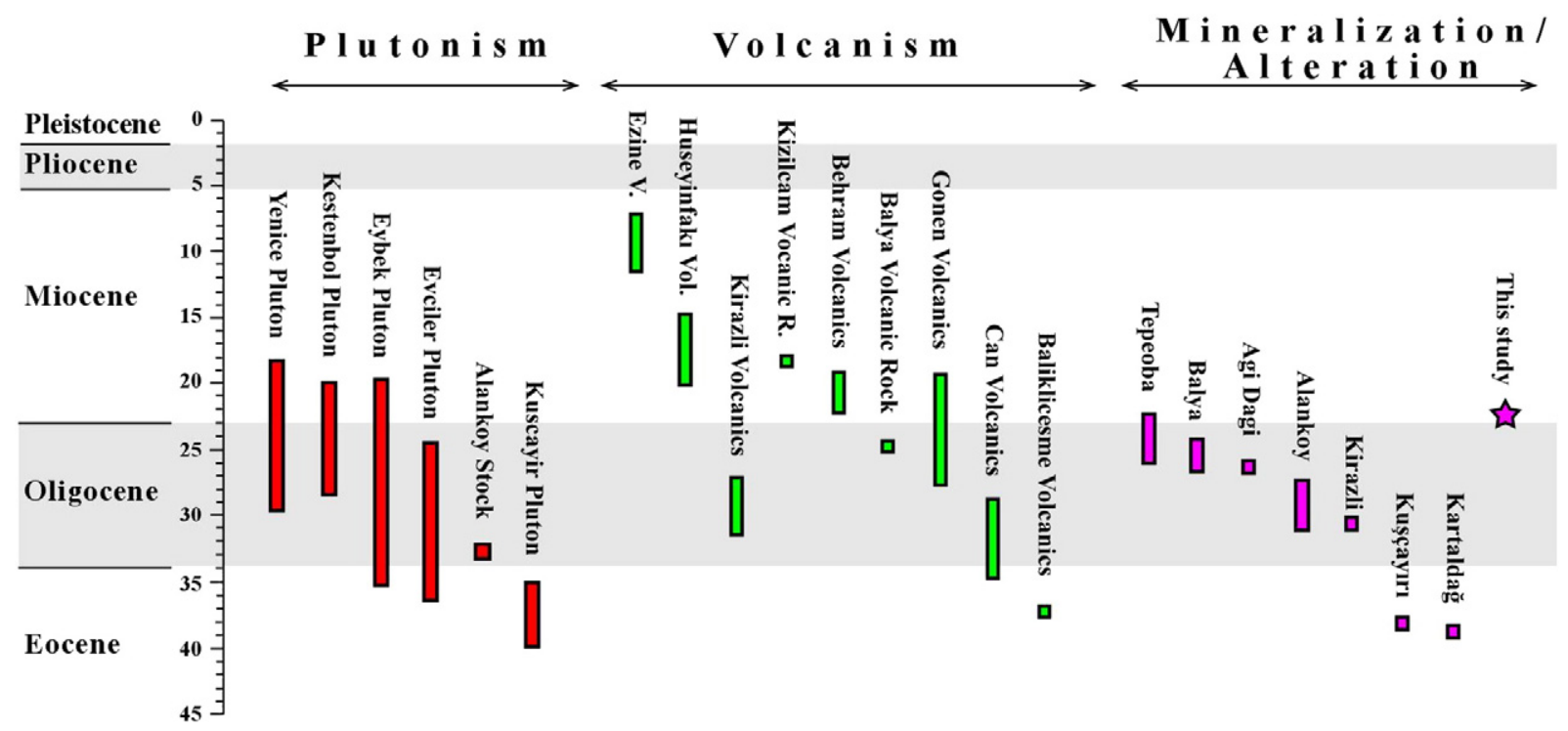

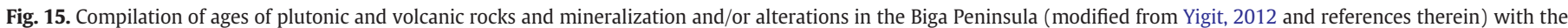
illitization age from this study.

$\delta \mathrm{D}$ and $\delta^{18} \mathrm{O}$ where the cooling line of water in equilibrium with illite, high temperature magmatic fluid, intersects the EMMW line at low temperature, supporting our earlier contention that the geothermal waters contain a significant component of the high temperature magmatic fluid.

\subsection{4. $\mathrm{Rb}$-Sr dating}

The crystal sizes of analyzed illites are commonly greater than $2 \mu \mathrm{m}$, as seen during SEM investigations (see Fig. 4), but do not contain any detrital micas because of their pristine volcanic-hydrothermal origin. Size fractions of $<2 \mu \mathrm{m}$ were extracted for $\mathrm{Rb}-\mathrm{Sr}$ age dating. The $\mathrm{Rb}-\mathrm{Sr}$ isotope data for the different sized clay fractions of samples from different locations are presented in Table 6 and plotted on a $\mathrm{Rb}-\mathrm{Sr}$ isochron diagram in Fig. 14. The slope of the linear relationship between ${ }^{87} \mathrm{Sr} /{ }^{86} \mathrm{Sr}$ and ${ }^{87} \mathrm{Rb} /{ }^{86} \mathrm{Sr}$ ratios for the whole data set corresponds to an age of $22.4 \pm 2.3 \mathrm{Ma}(\mathrm{MSWD}=2.4)$, with an initial ${ }^{87} \mathrm{Sr} /{ }^{86} \mathrm{Sr}$ ratio of $0.70694 \pm 0.00088$. The samples from different deposits are parts of the same linear relationship, and hence indicate precipitation from fluids with the same initial ${ }^{87} \mathrm{Sr} /{ }^{86} \mathrm{Sr}$ ratio. This requires a homogeneous fluid composition over large distances, probably due to the lithological similarity of the host rocks (Oligocene pyroclastic rocks) that the fluids interacted with in two different deposits.

\section{Discussion}

\subsection{Petrography}

The optical and SEM investigations of the altered pyroclastic rocks from the different deposits clearly show that the presence of clay minerals is related to hydrothermal alteration such as kaolinization and sericitization. There is no evidence of any detrital components (non-volcanic or extraclastic). The occurrence of illite is as finegrained micaceous (i.e., sericite) scaly aggregates spreading over the volcanic groundmass and filling the pore spaces. The presence of both illite and I-S with different crystal sizes in Koru sample may be indicative of either an intermediate stage for the progressive evolution from smectite to illite in other words illitization did not proceed to completion because of an inadequate temperature. In addition to this, illite and I-S may also be an indicator for subsequent occurrence, firstly illite at $\sim 300{ }^{\circ} \mathrm{C}$ and subsequently $\mathrm{I}-\mathrm{S}$, at $\sim 150{ }^{\circ} \mathrm{C}$, related to two different thermal events, based on the fluid inclusion data. The development of kaolinites was as authigenetic infillings of circular and ellipsoidal pore spaces (see Fig. 3). The SEM shows that the illite flakes and kaolinite/dickite booklets have a similar crystal size and morphology. Euhedral kaolinite, book-like platy aggregates, together with euhedral quartz crystals developed within the pores (see Fig. 4), indicating neo-crystallization or neo-formation directly from the hydrothermal fluids.

\subsection{Mineralogy}

The consistency of the grade derived from the illite KI values $\left(\Delta^{\circ} 2 \theta\right)$ and the homogenization temperatures of primary quartz-hosted fluid inclusions, indicates illite formation is compatible with hydrothermal alteration and not from detrital input or surficial weathering. The anchi-epimetamorphic KI values of the predominantly monomineralic illites, or fine-grained white K-micas (sericites), from Kumarlar and Tesbihdere, are indicative of the highest-temperature alteration conditions (i.e., phyllic alteration). A monomineralic phase is characteristic for hydrothermal vein sericitization as previously stated by several authors (Eberl et al., 1987; Parry et al., 2002). However, diagenetic illite/I-S and kaolinite from the Koru deposit are indicative of relatively lower temperature conditions. This principally relates to sample locations being further away from ore vein where the fluid temperatures would have been higher. The first order peak decomposition of Koru illite shows two types of illitic phases, as illite and I-S. The two illitic phases may be the result of either progressive evolution from the smectite to illite transformation or a subsequent occurrence related to two different thermal events. Fluid inclusion data (primary inclusions related to relatively high temperature conditions $\sim 300{ }^{\circ} \mathrm{C}$, secondary inclusions related to lower temperature conditions $\sim 150{ }^{\circ} \mathrm{C}$ ) support the latter origin. The low $d_{060}$ ( or $b$ cell dimension) values of illites, indicate low contents of octahedral $\mathrm{Mg}$ and $\mathrm{Fe}$, and are characteristic of a temperature control rather than a pressure effect (e.g., Sassi and Scolari, 1974; Guidotti and Sassi, 1986). Illites generally have a mixture of $1 M$ and $1 M_{d}$ polytypes, but $2 M_{1}$ is found in illite from Kumarlar associated with $1 M$ and $1 M_{d}$ polytypes. The dominance of $1 M$ illite and its presence in the anchi-epizonal grade $\left(>200{ }^{\circ} \mathrm{C}\right)$ was previously reported in hydrothermal alteration zones (Shirozu and Higashi, 1972; Meunier and Velde, 1982; Inoue et al., 1987, 1988; Drits et al., 1993; Inoue and Kitagawa, 1994; Drews-Armitage et al., 1996; Celik et al., 1999; Tillick et al., 2001; Yan et al., 2001; Bove et al., 2002; Schleicher et al., 2006). 


\subsection{Geochemistry}

The major element chemistry of host-rocks and illites show that illites have relatively high $\mathrm{Al}$ and low Fe and $\mathrm{Mg}$ contents as confirmed by low $d_{060}$ values. The enrichment of aluminum and potassium relative to sodium, calcium, magnesium and iron in illites (or fine grained micaceous occurrences, i.e., sericites) seems to be related to the host-rock composition and nature of hydrothermal alteration at a high water/ rock ratio and low pH conditions (Berger and Velde, 1992; Meunier and Velde, 2004). Similar compositions for hydrothermal illites associated with massive sulfide deposits from western Pontides was reported by Celik et al. (1999). Low Fe- and Mg-bearing illites associated with volcanic hosted hydrothermal ore deposits have been proposed by these authors as due to the presence of sulfides (pyrite, chalcopyrite) or oxides (hematite), and a low content of Mg in host-rock, respectively.

The similarity in the isotope composition and trends of the fluid inclusions trapped in quartz and illite-forming waters implies that these are likely to have the same origin. The extension of the isotopic compositions of illite-forming waters along the fractionation trends from high to low temperatures would intersect close to the present day local meteoric or geothermal water but at more negative $\delta \mathrm{D}$ values than the estimate of meteoric water at the time of mineralization (Fig. 12). The common interpretation is that this shows mixing between meteoric and magmatic fluids, but there is no other evidence to support this hypothesis. Fluid inclusion data does not support a cooling and dilution trend as would be expected, rather the Th values are, within error, constant as is the salinity. Therefore, we interpret the fluid isotopic data as showing the cooling of the initial high temperature magmatic fluid, while maintaining a state of near equilibrium with the alteration products produced by this fluid. As can be seen on Fig. 12, such fluids would plot in the same area of the $\delta^{18} \mathrm{O}-\delta \mathrm{D}$ diagram as the measured fluid inclusion isotope data. Fluid inclusion evidence for Tesbihdere and Arapucandere (Bozkaya et al., 2014, Bozkaya and Banks, 2015) show the magmatic high temperature fluids flashed and boiled when the pressure changed from lithostatic to hydrostatic or lower at depths of approximately $600 \mathrm{~m}$. In a hydrostatic system, as would be required for meteoric waters to descend and mix with the higher temperature magmatic fluids, the pressure would be too low to prevent boiling of the meteoric water at lower temperatures and therefore any mixing of these two fluids would produce a trend of decreasing temperatures which is not observed in the fluid inclusion data. For a fluid at $300{ }^{\circ} \mathrm{C}$ in a hydrostatic system, a depth of some $1600 \mathrm{~m}$ would be required to prevent boiling and this does not fit with the geological evidence, i.e., amount of material eroded from the top of the deposit or the normal model depth for epithermal mineralization. Therefore, the intersection of the trends in Fig. 12 with the present day local geothermal waters and the position of fluid inclusion $\delta \mathrm{D}$ and $\delta^{18} \mathrm{O}$ values do not imply a significant involvement of local meteoric water, at the time of mineralization. In any cases the best estimate of meteoric water at the time of mineralization, which is at more positive $\delta \mathrm{D}$ values on the MWL, perhaps shows the effect of the magmatic vapor/low salinity liquid ascending to near the surface today. It does not indicate that meteoric water is the dominant fluid in the mineralized system, which was undoubtedly magmatic.

\subsection{Age of mineralization}

The $\mathrm{Rb}-\mathrm{Sr}$ age of illites indicates that the illites were developed in the lowermost Miocene. According to age distribution of volcanic and plutonic rocks, and alterations or mineralizations in the Biga Peninsula (Fig. 15), this age corresponds with that of the Tepeoba porphyry $\mathrm{Cu}-$ Mo-Au deposit, which is related to Late Oligocene granodioritic and granitic porphyries intruded into metabasic and metasedimentary rocks (Yigit, 2012). The age approximately corresponds to the age of the many plutons in the Biga Peninsula (Upper Oligocene-Lower Miocene, Figs. 1 and 15), indicating the heat and source of the hydrothermal fluids is primarily related to plutonic intrusions. In other words, plutonic intrusions that are related to latest Oligocene-Early Miocene extension (Bonev and Beccaletto, 2007; Yigit, 2012) are the main cause of hydrothermal activity in the Biga Peninsula.

\section{Conclusions}

The crystal-chemical and geochemical (major, trace and isotope) data of illites from the hydrothermal alteration zones in three volcanic-hosted base-metal deposits in the Biga Peninsula shows that illite, as a product of alteration caused by hydrothermal fluids, can be used to better understand some aspects (i.e., origin of fluids, temperature conditions, age of hydrothermal activity etc.) and supports evidence from other techniques primarily related to the fluids of the mineralizing system. The illites in this study have similar mineralogical and geochemical properties to hydrothermal illites from several deposits around the world. The subhedral and euhedral shapes indicating a neocrystallization origin, the dominance of $1 \mathrm{M}$ and $1 \mathrm{M}_{\mathrm{d}}$ polytypes, low $d_{060}$ values, low octahedral $\mathrm{Mg}+$ Fe contents are similar despite the different temperature conditions. KI values are compatible with the temperature data obtained from fluid inclusions in quartz and sphalerite, thus the KI values of illite can be used in estimating temperature conditions for alteration products when fluid inclusion data is not available. The stable isotope data, $\delta \mathrm{D}$ and $\delta^{18} \mathrm{O}$, of illite from both deposits plots close to the magmatic water box (Fig. 12) indicating that the hydrothermal fluids producing these alteration products were predominantly of magmatic water. The values are also consistent with the $\delta \mathrm{D}$ and $\delta^{18} \mathrm{O}$ values obtained from fluid inclusions and host quartz that also plot close to the mineral data and indicate a dominantly magmatic fluid.

The calculated fractionation trends of fluids in equilibrium with the products of alteration at lower temperatures is close to the $\delta \mathrm{D}$ and $\delta 180$ values from fluid inclusions and host quartz, plotting between the magmatic box and the meteoric water line. In this study, we show that this process is a more likely alternative to the conventional interpretation that data plotting in these areas of the $\delta \mathrm{D}$ and $\delta 180$ diagram represent mixing of magmatic and meteoric waters.

The ability to determine the age of the alteration, by using $\mathrm{Rb} / \mathrm{Sr}$ data of the illites, is advantageous as in this case a clear link to the age of mineralization, determined by other methods or on different samples can be made. Dating the products of the mineralizing fluids clearly provides a better age than dating the enclosing volcanic rocks, which is the more common approach in the Biga Peninsula. The latest Oligocene and lowest Miocene age of illites indicates plutonic intrusions related to extensional tectonic regime in the Biga Peninsula, are the main cause of hydrothermal activities that led to the numerous mineral deposits. The type and products of fluid-rock interactions can therefore be linked with the deposition of ores and provided constraints on the physicochemical conditions during mineralization. Thus, it is possible to more fully understand and model this type of mineralizing system.

We have shown that utilizing mineralogical and geochemical data from illites in combination with data from fluid inclusions and their host quartz has some important advantages over interpreting fluid inclusion data in isolation. Therefore illites or illite-bearing mixed layers (I-S) can be of use for better understanding the age and conditions of hydrothermal ore fluids.

\section{Acknowledgments}

The first two authors thank to Prof. Dr. Hüseyin Yalcin and Prof. Dr. Ahmet Gökce, the directors of the Mineralogy-PetrographyGeochemistry, Ore Petrography and Fluid Inclusion Laboratories in Cumhuriyet University, Sivas, Turkey, for their laboratory and scientific supports. We also thank to Assoc. Prof. Dr. Nazan Keskin, the director of Electron Microscopy Laboratories in Pamukkale University, for providing help during SEM-EDS experiments. Radiometric dating and stable 
isotope work of this research was funded through a grant from the Queensland State Government allocated to the Queensland Geothermal Energy Centre of Excellence (QGECE). Support by Hal Gurgenci (former QGECE's director) is particularly acknowledged. We thank Yue-xing Feng and Ai Duc Nguyen for their help with analytical work and technical assistance to perform $\mathrm{Rb}-\mathrm{Sr}$ and trace element analyses. The authors also thank to Prof. Dr. Selahattin Kadir and an anonymous reviewer for their constructive reviews.

\section{References}

Aldanmaz, E., Pearce, J.A., Thirlwall, M.F., Mitchell, J.G., 2000. Petrogenetic evolution of late Cenozoic, post-collision volcanism in western Anatolia, Turkey. J. Volcanol. Geotherm. Res. 102, 67-95.

Bailey, S.W., 1988. X-ray diffraction identification of the polytypes of mica, serpentine, and chlorite. Clay Clay Miner. 36, 193-213.

Bauluz, B., 2007. Illitization processes: series of dioctahedral clays and mechanisms of formation. In: Nieto, F., Millan, J. (Eds.). Diagenesis and Low-Temperature Metamorphism. Theory, Methods and Regional Aspects. Seminarios de la Sociedad Española de Mineralogía. Volumen 3, Sociedad Española de Mineralogía, Jaén, pp. 31-39.

Bauluz, B., Peacor, D.R., Ylagan, R.F., 2002. Transmission electron microscopy study of smectite illitization during hydrothermal alteration of a rhyolitic hyaloclastite from Ponza, Italy. Clay Clay Miner. 50, 157-173.

Bechtel, A., Hoernes, S., 1990. Oxygen isotope fractionation between oxygen of different sites in illite minerals: a potential single-mineral thermometer. Contrib. Mineral. Petrol. 104, 463-470.

Berger, G., Velde, B., 1992. Chemical-parameters controlling the propylitic and argillic alteration process. Eur. J. Mineral. 4, 1439-1455.

Birkle, P., Satir, M., 1995. Dating, geochemistry and geodynamic significance of the tertiary magmatism of the Biga Peninsula, NW Turkey. In: Erler, A., Ercan, T., Bingöl, E., Örçen, S. (Eds.), The Geology of the Black Sea Region. Directorate of Mineral Research and Exploration, Ankara, pp. 171-180.

Bonev, N., Beccaletto, L., 2007. From syn- to post-orogenic tertiary extension in the North Aegean region: constraints on the kinematics in the eastern Rhodope-Thrace, Bulgaria-Greece and the Biga Peninsula, NW Turkey. In: Taymaz, T, Yilmaz, Y, Dilek, Y. (Eds.). The Geodynamics of the Aegean and Anatolia, Geol. Soc. Lond., Spec. Publ. 291, 113-142.

Bove, D.J., Eberl, D.D., McCarty, D.K., Meeker, G.P., 2002. Characterization and modeling of illite crystal particles and growth mechanisms in zoned hydrothermal deposit, Lake City, Colorado. Am. Mineral. 87, 1546-1556.

Bozkaya, G., 2001. Geology of Koru (Çanakkale) Barite Bearing Lead-Zinc deposits. (PhD Thesis), University of Cumhuriyet, $126 \mathrm{p}$ (unpublished).

Bozkaya, G., Banks, D.A., 2014. Sulfur isotope geochemistry and mineralogy of balcilar vein type barite-sulphide mineralization, Biga Peninsula, NW Turkey. Pamukkale Univ. J. Eng. Sci. http://dx.doi.org/10.5505/pajes.2014. 87699 (in press).

Bozkaya, G., Banks, D.A., 2015. Physico-chemical controls on ore deposition in the arapucandere $\mathrm{Pb}-\mathrm{Zn}-\mathrm{Cu}$-precious metal deposit, Biga Peninsula, NW Turkey. Ore Geol. Rev. 66, 65-81.

Bozkaya, G., Celik, S., 2010. (20th General Meeting of the International Mineralogical Association (IMA), Eötvös Lorand University, Budapest, 21-27 August, 2010. Abstract Volume). The origin of hydrothermal fluids in the Kumarlar Pb-Zn veins, Canakkale, NW Turkey. p. 79.

Bozkaya, G., Gokce, A., 2001. Geology, ore petrography and fluid inclusion characteristics of the Koru (Çanakkale) Pb-Zn deposits. Cumhuriyet Univ. Bull. Fac. Eng. Ser. A Earth Sci. $18,55-70$

Bozkaya, G., Gokce, A., 2007. Fluid inclusion and isotope geochemistry studies of the galena-barite veins in Balcllar (Lapseki-Çanakkale) area. Abstract of 60th Geological Congress of Turkey, pp. 188-190.

Bozkaya, G., Gokce, A., 2009. Lead and sulfur isotope studies of the Koru (Canakkale, Turkey) lead-zinc deposits. Turk. J. Earth Sci. 18, 127-137.

Bozkaya, Ö., Bozkaya, G., Yalcin, H., Gokce, A., 2007. Diagenetic, hydrothermal and surface alterations in the Eocene aged pyroclastic rocks in the vicinity of Koru $\mathrm{Pb}-\mathrm{Zn}$ deposits. 13th National Clay Symposium, 12-14 September 2007. Suleyman Demirel University, Isparta, Proceedings, pp. 80-96.

Bozkaya, G., Banks, D.A., Ozbas, F., Wallington, J., 2014. Fluid processes in the Tesbihdere base-metal-Au deposit: implications for epithermal mineralization in the Biga Peninsula, NW Turkey. Cent. Eur. J. Geosci. 6, 148-169.

Browne, P.R.L., Ellis, A.J., 1970. The Ohaaki-Broadlands hydrothermal area, New Zealand: mineralogy and related geochemistry. Am. J. Sci. 269, 97-131.

Buatier, M.D., Peacor, D.R., O'Neil, J.R., 1992. Smectite-illite transition in Barbados accretionary wedge sediments: TEM and AEM evidence for dissolution/crystallization at low temperature. Clay Clay Miner. 40, 65-80.

Campbell, A.R., Larson, P.B. 1988. Introduction to stable isotope applications in hydrothermal systems. In: Richards, J.P., Larson, P.B. (Eds.). Reviews in Economic Geology, vol. 10, Society of Economic Geologists, pp. 173-193.

Celik, M., Karakaya, N., Temel, A., 1999. Clay minerals in hydrothermally altered volcanic rocks, Eastern Pontides, Turkey. Clay Clay Miner. 47, 708-717.

Craig, H., 1961. Isotopic variations in meteoric waters. Science 133, 1702-1703.

Drews-Armitage, S.P., Romberger, S.B., Whitney, C.G., 1996. Clay alteration and gold deposition in the genesis and blue star deposits, Eureka County, Nevada. Econ. Geol. 91, 1383-1393.
Drits, V.A., Weber, F., Salyn, A.L., Tsipursky, S.I., 1993. X-ray identification of one-layer illite varieties: application to the study of illites around uranium deposits of Canada. Clay Clay Miner. 41, 389-398.

Duba, D., William-Jones, A.E., 1983. The application of illite crystallinity, organic matte reflectance and isotopic techniques to mineral exploration: a case study in southwestern Gasp6, Quebec. Econ. Geol. 78, 1350-1363.

Eberl, D.D., Velde, B., 1989. Beyond the Kübler index. Clay Miner. 24, 571-577.

Eberl, D.D., Środoń, J., Lee, M., Nadeau, P.H., Northrop, H.R., 1987. Sericite from the Silverton caldera, Colorado: correlation among structure, composition, origin, and particle thickness. Am. Mineral. 72, 914-934.

Ece, Ö.I., Schroeder, P.A., Smilley, M.J., Wampler, J.M., 2008. Acid-sulfate hydrotherma alteration of andesitic tuffs and genesis of halloysite and alunite deposits in the Biga Peninsula, Turkey. Clay Miner. 43, 281-315.

Eggins, S.M., Woodhead, J.D., Kinsley, L.P.J., Mortimer, G.E., Sylvester, P., McCulloch, M.T. Hergt, J.M., Handler, M.R., 1997. A simple method for the precise determination of $\geq 40$ trace elements in geological samples by ICPMS using enriched isotope internal standardisation. Chem. Geol. 134, 311-326.

Eisenlohr, T., 1997. The thermal springs of the Armutlu Peninsula (NW Turkey) and their relationship to geology and tectonics in active tectonics of Northwestern Anatolia-The Marmara Poly Project. In: Pfister, M. (Ed.), vdf Hochschulverlag AG an der ETH Zurich, pp. 197-228.

Ercan, T., Satir, M., Steinitz, G., Dora, A., Sarifakioglu, E. Adis, C., Walter, H., Yildirim, T. 1995. Characteristics of tertiary volcanism in the Biga Peninsula and Gökçeada Bozcaada and Tavsan islands (NW Anatolia). Bull. Mineral Res. Explor. Inst. Turk 117, 55-86 (in Turkish with English abstract).

Ercan, T., Turkecan, A., Guillou, H., Satir, M., Sevin, D., Saroglu, F., 1998. Features of the tertiary volcanism around the Sea of Marmara. Bull. Mineral Res. Explor. Inst. Turk. 120 199-222 (in Turkish with English abstract).

Frey, M., Teıchmıüller, M., Teıchmüller, R., Mullıs, J., Konzi, B., Breıtschmid, A., Gruner, U. Schwizer, B., 1980. Very low-grade metamorphism in external parts of the central Alps: illite crystallinity, coal rank and fluid inclusion data. Eclogae Geol. Helv. 73 173-203.

Fukuchi, R., Fujimoto, K., Kameda, J., Mari Hamahashi, M., Yamaguchi, A., Kimura, G., Hamada, Y., Hashimoto, Y., Kitamura, Y., Saito, S., 2014. Changes in illite crystallinity within an ancient tectonic boundary thrust caused by thermal, mechanical, and hydrothermal effects: an example from the Nobeoka Thrust, southwest Japan. Earth Planets Space 66, 116.

Gat, J.R., Shemesh, A., Tziperman, E., Hecht, A., Georgopoulus, D., Basturk, O., 1996. The stable isotope composition of waters of the eastern Mediterranean Sea. J. Geophys. Res. 101, 6441-6451.

Golding, S.D., Uysal, I.T., Glikson, M., Baublys, K.A., Southgate, P.N., 2006. Timing and chemistry of fluid-flow events in the Lawn Hill platform, northern Australia. Econ Geol. 101, 1231-1250.

Grathoff, G.H., Moore, D.M., 1996. Illite polytype quantification using Wildfire® calculated X-ray diffraction patterns. Clay Clay Miner. 44, 835-842.

Guidotti, C.V., Sassi, F.P., 1986. Classification and correlation of metamorphic facies series by means of muscovite b0 data from low-grade metapelites. Neues Jb. Mineral. Abh. $153,363-380$

Guidotti, C.V., Mazzoli, C., Sassi, F.P., Blencoe, J.G., 1992. Compositional controls on the cell dimensions of 2M1 muscovite and paragonite. Eur. J. Mineral. 4, 283-297.

Harvey, C.C., Browne, P.R.L., 1991. Mixed-layer clay geothermometry in the Wairakei geothermal field, New Zealand. Clay Clay Miner. 39, 614-621.

Hedenquist, J.W., Browne, P.R.L., 1989. The evolution of the Waiotapu geothermal system, New Zealand, based on the chemical and isotopic composition of its fluids, minerals and rocks. Geochim. Cosmochim. Acta 53, 2235-2257.

Inoue, A., 1995. Formation of clay minerals in hydrothermal environments. In: Velde, B. (Ed.), Origin and Mineralogy of Clays. Springer, Berlin, pp. 268-330.

Inoue, A., Kitagawa, R., 1994. Morphological characteristics of illitic clay minerals from a hydrothermal system. Am. Mineral. 79, 700-711.

Inoue, A., Kohyama, N., Kitagawa, R., Watanabe, T., 1987. Chemical and morphological evidence for the conversion of smectite to illite. Clay Clay Miner. 35, 111-120.

Inoue, A., Velde, B., Meunier, A., Touchard, G., 1988. Mechanism of illite formation during smectite-to-illite conversion in a hydrothermal system. Am. Mineral. 73, 1325-1334.

Jagodzinski, H., 1949. One dimensional disorder in crystals and their influence on X-ray interferences: I. Calculation of the degree of disorder from the X-ray intensities. Acta Crystallogr. 2, 201-207 (in German).

Jankovic, S., 1986. Tethyan Eurasian metallogenic belt: relations of mineral associations and their tectonic setting. Geotecton. Metallog. 10, 99-124.

Jennings, S., Thompson, G.R., 1986. Diagenesis in Plio-Pleistocene sediments in the Colorado River delta, southern California. J. Sediment. Petrol. 56, 89-98.

Ji, J., Browne, P.R.L., 2000. Relationship between illite crystallinity and temperature in active geothermal systems of New Zealand. Clay Clay Miner. 48, 139-144.

Jingwen, M., Pirajno, F., Lehmann, B., Maocheng, L., Berzina, A., 2014. Distribution of porphyry deposits in the Eurasian continent and their corresponding tectonic settings. J. Asian Earth Sci. 79, 576-584.

Krumm, S., 1996. WINFIT 1.2: version of November 1996 (the Erlangen geological and mineralogical software collection) of WINFIT 1.0: a public domain program for interactive profile-analysis under WINDOWS. XIII Conference on Clay Mineralogy and Petrology, Praha, 1994. Acta Univ. Carol. Geol. 38, 253-261.

Kübler, B., 1968. Evaluation quantitative du métamorphisme par la cristallinité de l'illite. Bull. Centre Rech. Pau-SNPA. 2, 385-397.

Ludwig, K.R., 2003. User's Manual for Isoplot 3.00. A geochronological Toolkit for Microsoft Excel, Berkeley Geochronology Center, Special Publication, No. 4a, Berkeley, California. 
Merriman, R.J., Frey, M., 1999. Patterns of very low-grade metamorphism in metapelitic rocks. In: Frey, M., Robinson, D. (Eds.), Low Grade Metamorphism, Blackwell, Oxford, pp. 61-107.

Meunier, A., Velde, B., 1982. X-ray-diffraction of oriented clays in small quantities (0.1 mg). Clay Miner. 17, 259-262.

Meunier, A., Velde, B., 2004. Illite: Origins, Evolution and Metamorphism. Springer-Verlag, Berlin (286 pp).

Middleton, A.W., Uysal, I.T., Bryan, S.E., Hall, C.M., Golding, S.D., 2014. Integrating ${ }^{40} \mathrm{Ar}-{ }^{39} \mathrm{Ar},{ }^{87} \mathrm{Rb}-{ }^{87} \mathrm{Sr}$ and ${ }^{147} \mathrm{Sm}-{ }^{143} \mathrm{Nd}$ geochronology of authigenic illite to evaluate tectonic reactivation in an intraplate setting, central Australia. Geochim. Cosmochim. Acta $134,155-174$

Middleton, A.W., Uysal, I.T., Golding, S.D., 2015. Chemical and mineralogical characterisation of illite-smectite: implications for episodic tectonism and associated fluid flow, Central Australia. Geochim. Cosmochim. Acta 148, 284-303.

Moore, D.M., Reynolds, R.C., 1997. X-ray Diffraction and the Identification and Analysis of Clay Minerals. Oxford University Press, New York (378 p).

Okay, A.I., Siyako, M., Bürkan, K.A., 1990. Geology and tectonic of the Biga Peninsula. Turk. Assoc. Pet. Geol. Bull. 2, 83-121 (in Turkish with English abstract).

Okay, A.I., Siyako, M., Bürkan, K.A., 1991. Geology and tectonic evolution of the Biga Peninsula. Bull. Tech. Univ. Istanbul 44, 191-255.

Parry, W.T., Jasumback, M., Wilson, P.N., 2002. Clay mineralogy of phyllic and intermediate argillic alteration at Bingham, Utah. Econ. Geol. 97, 221-239.

Pollastro, R.M., 1993. Considerations and applications of the illite/smectite geothermometer in hydrocarbon-bearing rocks of Miocene to Mississippian age. Clay Clay Miner. 41, 119-133.

Ramseyer, K., Boles, J.R., 1986. Mixed-layer illite/smectite minerals in tertiary sandstones and shales, San Joaquin basin, California. Clay Clay Miner. 34, 115-124.

Reynolds, R.C., 1980. Interstratified clay minerals. In: Brindley, G.W., Brown, G. (Eds.) Crystal Structures of Clay Minerals and Their X-ray Identification, Mineralogical Society, London, pp. 249-303.

Reynolds Jr., R.C., 1985. NEWMOD@ A computer program for the calculation of onedimensional diffraction patterns of mixed layered clays R. C. Reynolds, Jr., 8 Brook Dr., Hanover.

Roedder, E., 1984. In: Ribbe, P.H. (Ed.), Fluid Inclusions, Reviews in Mineralogy vol. 12 Mineralogical Society of America (644 p).

Sassi, F.P., Scolari, A., 1974. The $b_{0}$ value of the potassic white micas as a barometric indicator in low-grade metamorphism of pelitic schists. Contrib. Mineral. Petrol. 45, $143-152$.

Savin, S.M., Lee, W., 1988. Isotopic studies of phyllosilicates. In: Bailey, S.W. (Ed.), Hydrous Phyllosilicates (Exclusive of Micas). Reviews in Mineralogy, 19. Mineralogical Society of America, Washington, D.C., pp. 189-223.

Schleicher, A.M., Warr, L.N., Kober, B., Laverret, E., Clauer, N., 2006. Episodic mineralization of hydrothermal illite in the Soultz-sous-Forêts granite, Upper Rhine Graben/France. Contrib. Mineral. Petrol. 152, 349-364.

Schmid, R., 1981. Descriptive nomenclature and classification of pyroclastic deposits and fragments: recommendations of the IUGS subcommission on the systematics of igneous rocks. Geology 9, 41-43.

Sharp, Z.D., 1990. Laser-based microanalytical method for the in situ determination of oxygen isotope ratios of silicates and oxides. Geochim. Cosmochim. Acta 54, 1353-1357.

Sheppard, S.M.F., Nielsen, R.L., Taylor, H.P.J., 1969. Oxygen and hydrogen isotope ratios of clay minerals from porphyry copper deposits. Econ. Geol. 64, 755-777.

Shirozu, H., Higashi, S., 1972. X-ray examination of sericite minerals associated with Kuroko deposits. Clay Sci. 4, 137-142.

Siyako, M., Burkan, K.A., Okay, A.I., 1989. Tertiary geology and hydrocarbon potential of the Biga and Gelibolu Peninsulas. Turk. Assoc. Pet. Geol. Bull. 1, 183-199 (in Turkish with English abstract).
Środoń, J., 1984. X-ray powder diffraction identification of illitic materials. Clay Clay Miner. 32, 337-349.

Tillick, D.A., Peacor, D.R., Mauk, J.L., 2001. Genesis of dioctahedral phyllosilicates during hydrothermal alteration of volcanic rocks: I. The golden cross epithermal ore deposit, New Zealand. Clay Clay Miner. 49, 126-140.

Uysal, I.T., Golding, S.D., Thiede, D.S., 2001. K-Ar and Rb-Sr dating of authigenic illitesmectite in Late Permian coal measures, Queensland, Australia: implication for thermal history. Chem. Geol. 171, 195-211.

Uysal, I.T., Gasparon, M., Bolhar, R., Zhao, J.-X., Feng, Y.-X., Jones, G., 2011. Trace element composition of near-surface silica deposits-a powerful tool for detecting hydrothermal mineral and energy resources. Chem. Geol. 280, 154-169.

Velde, B., Vasseur, G., 1992. A kinetic model of the smectite to illite transformation based on diagenetic mineral series. Am. Mineral. 77, 967-976.

Warr, L.N., Rice, A.H.N., 1994. Interlaboratory standardization and calibration of clay mineral crystallinity and crystallite size data. J. Metamorph. Geol. 12, 141-152.

Weaver, C.E., Pollard, L.D., 1973. The Chemistry of C1ay Minerals. Developments in Sedimentology, 15. Elsevier, Amsterdam (213pp).

Whitney, G., 1990. Role of water in the smectite-to-illite reaction. Clay Clay Miner. 38, 343-350.

Yan, Y., Tillick, D.A., Peacor, D.R., Simmons, S.F., 2001. Genesis of dioctahedral phyllosilicates during hydrothermal alteration of volcanic rocks: the Broadlands hydrothermal system, New Zealand. Clay. Clay Miner. 49, 141-155.

Yanagiya, K., Sato, J., 1989. Report on the mineral exploration in the Canakkale area, Republic of Turkey. MTA Report No: 8999. Phase I-II (132 p).

Yeh, H.-W., 1980. D/H ratios and late stage dehydration of shales during burial. Geochim. Cosmochim. Acta 44, 341-352.

Yigit, O., 2009. Mineral deposits of Turkey in relation to Tethyan metallogeny: implications for future mineral exploration. Econ. Geol. 104, 19-51.

Yigit, O., 2012. A prospective sector in the Tethyan Metallogenic Belt: geology and geochronology of mineral deposits in the Biga Peninsula, NW Turkey. Ore Geol. Rev. $46,118-148$

Yilmaz, Y., 1990. Comparison of young volcanic associations of western and eastern Anatolia formed under a compressional regime: a review. J. Volcanol. Geotherm. Res. 44, 69-87.

Yilmaz, H., 2002. Ovacik gold deposit: an example of quartz-adularia-type gold mineralization in Turkey. Econ. Geol. 97, 1829-1839.

Yilmaz, Y., Genc, S.C., Karacik, Z., Altunkaynak, S., 2001. Two contrasting magmatic associations of NW Anatolia and their tectonic significance. J. Geodyn. 31, 243-271.

Yilmaz, H., Oyman, O., Arehart, G.B., Colakoglu, A.R., Billor, Z., 2007. Low-sulfidation type Au-Ag mineralization at Bergama, Izmir, Turkey. Ore Geol. Rev. 32, 81-124.

Yilmaz, H., Oyman, T., Sönmez, F.N., Arehart, G.B., Billor, Z., 2010. Intermediate sulfidation epithermal gold-base metal deposits in Tertiary subaerial volcanic rocks, Sahinli/ Tespih Dere (Lapseki/Western Turkey). Ore Geol. Rev. 37, 236-258.

Zhangdong, J., Jinchu, Z., Junfeng, J., Xinwei, L., Fuchun, L., 2001. Ore-forming fluid constraints on illite crystallinity (IC) at Dexing porphyry copper deposit, Jiangxi Province. Sci. China Ser. D Earth Sci. 44, 177-184

Zhangdong, J., Jinchu, Z., Junfeng, J., Xinwei, L., Fuchun, L., Xinwei, L., 2002. Two origins of illite at the Dexing porphyry Cu deposit, East China: Implications for ore-forming fluid constraint on illite crystallinity. Clay Clay Miner. 50, 381-387.

Zwingmann, H., Clauer, N., Gaupp, R., 1999. Structure related geochemical (REE) and isotopic ( $\mathrm{K}-\mathrm{Ar}, \mathrm{Rb}-\mathrm{Sr}, \delta^{18} \mathrm{O}$ ) characteristics of clay minerals from Rotliegend sandstone reservoirs (Permian, northern Germany). Geochim. Cosmochim. Acta 63, 2805-2823. 